\title{
GEÇMİŞTEN GÜNÜMÜZE DİNLER TASNİFİNDE MORFOLOJİK YAKLAŞIM
}

\author{
(1) Şevket ÖZCAN*
}

Öz

XIX. yüzyılın ikinci yarısından itibaren dinler tasnifi teşebbüslerinin artarak çoğalması ve ortaya çıkan tasniflerin dini araştırmalarda kullanılmasının sonucunda dinleri tasnif etme yaklaşımları ön plana çıkmıştır. Dinler Tarihinde coğrafi yaklaşımın yaygınlığına rağmen morfolojik yaklaşımın yadsınamaz şekilde cezp ediciliğe sahip olduğu ve konunun ilk defa bu bağlamda belli bir sistematiğe kavuştuğu ve dinamik hale geldiği belirtilmektedir. XIX. Yüzyllın ikinci yarısında hâkim olan ve XX. Yüzyılın ortalarına kadar Batı'daki dini araștırmalarda kullanılan dinin kaynağına ilișkin teoriler morfolojik dinler tasnifinin ilk tezahürleri niteliğindedir. Morfolojik dinler tasnifini sistematize eden din bilimcisi olma payesini ise Din Fenomenolojisinin mimarlarından Cornelius Petrus Tiele hak etmiștir. Çünkü Tiele'nin dinleri ahlaki dinler olarak kategorize edip evrensel dinlere/dünya dinlerine alt kategoride yer vermesi morfolojik dinler tasnifi açısından bir dönüm noktası olmuş ve yapılan morfolojik dinler tasniflerini etkilemiștir. Tiele'nin dünya dinleri kavramını İngilizceye kazandırması akademik ve popüler Dinler Tarihi çalışmalarının, Hıristiyanlık, Budizm, İslam, Hinduizm ve Yahudilik dinlerinin daimî üye olduğu; Konfüçyanizm, Taoizm, Şintoizm, Caynizm, Sihizm ve Zerdüştilik dinlerinin ise sıklıkla kullanıldığı bir dinler listesi ekseninde şekillenmesine kadar uzanmıştır. Jonathan Z. Smith ve Tomoko Masuzawa gibi din bilimcilerinin politik ve teolojik varsayımlara dayandığı gerekçesiyle eleştirdikleri bu durum, James L. Cox tarafından dünya dinleri paradigması şeklinde nitelendirilmiş ve dinleri daha iyi anlamak ve yerli dinleri de araştırmalara dâhil etmek için aşılması gereken bir problem olarak görülmüştür. Günümüzde özellikle batılı Dinler Tarihi çalışmaları incelendiğinde dünya dinleri kavramının üst bir kategori olarak kullanılmakta olduğunu ve belli başlı dinleri kapsayan bir dinler listesi sunduğunu görmek ve bu durumun alandaki pek çok çalışmayı kapsadığını söylemek mümkündür.

Anahtar kelimeler: Dinler Tarihi, Dinler, Tasnif, Morfoloji, Dünya Dinleri.

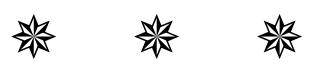

\footnotetext{
* Dr. Öğr. Üyesi, Kırıkkale Üniversitesi, ozcan.sevket06@gmail.com
} 


\section{MORPHOLOGICAL APPROACH IN CLASSIFICATION OF RELIGIONS FROM THE PAST TO PRESENT}

The origins of researching the religious beliefs of others by modern historians of history, it is based to the $5^{\text {th }}$ centuries BC. Therefore, evolving and expanding data about religious beliefs and practices in the historical process made it necessary to use different methods and approaches that will enable to understand and analyze this data in a correct, systematic and comprehensively way. In this context, the method of classifying religions according to certain categories within in the framework of the religious materials obtained has been formed and has been used by updating by many Eastern and Western religious researchers from the past to the present. From the second half of the nineteenth century, approaches of classification of religions have take over with increasing the number of classification of religions attempts and their using in religious studies.

[The Extended Abstract is at the end of the article.]

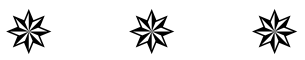

\section{Giriş}

Modern dönem dinler tarihçileri tarafından başkalarının dini inanışlarını araştırma konusu yapmanın kökeni M. Ö. V. yüzyıllara kadar dayandırılmaktadır. ${ }^{1}$ Dolayısıyla tarihi süreçte dini inanışlar ve pratikler hakkında gelişen ve çoğalan bilgiler, bu bilgileri doğru, sistematik ve etraflı biçimde anlama ve analiz etmeyi sağlayacak farklı yöntem ve yaklaşımları kullanmayı gerekli kılmıştır. Bu doğrultuda elde edilen dini malzemeler çerçevesinde dinleri belli kategorilere göre tasnif etme yöntemi teşekkül etmiş ve geçmişten günümüze pek çok doğulu ve batılı din araştırmacısı tarafından güncellenerek kullanılagelmiştir. Özellikle XIX. yüzyılın ikinci yarısından itibaren dinler tasnifi teşebbüslerinin artarak çoğalması ve ortaya çıkan tasniflerin dini araştırmalarda kullanılmasıyla birlikte dinleri tasnif etme yaklaşımları ön plana çıkmıştır. Ancak hali hazırda Dinler Tarihi metodolojisiyle ilgilenen dinler tarihçileri tarafından bu konunun pek çok soruyu ve sorunu ihtiva ettiği vurgulanırken, ${ }^{2}$ hangi açıdan yaklaşılırsa yaklaşılsın dört dörtlük bir dinler tasnifi yapmanın fazla mümkün

1 Jonathan Z. Smith, Map is Not Territory: Studies in the History of Religions (Chicago, London: The University of Chicago Press, 1993), 245; Eric J. Sharpe, Dinler Tarihi: Tarihsel Bir Anlatı, çev. Fuat Aydın (Sakarya: Sakarya Üniversitesi Kültür Yayınları, 2013), 18; Bu görüşün temellendirilmesi hakkında bk. Şevket Özcan, "Ancient Origins of the History of Religions: Herodotus Example", Illahiyat Tetkikleri Dergisi 51/1 (2019): 395-417.

2 Bk. Harry B. Partin, "Classification of Religions", Encyclopedia of Religion (Second Edition), ed. Lindsay Jones (New York: Macmillan Reference, 2005), 3: 1817-1822; Abdurrahman Küçük v. dğr., Dinler Tarihi (Ankara: Berikan Yayınevi, 2009), 28-29. 
görünmediği belirtilmiştir. ${ }^{3}$

Genel olarak dinler tasnifinin temel iki özelliği; ortak unsurları olan tarihi dini toplulukları gruplandırmak ve bir bütün olarak dini tecrübenin yapısını ortaya çıkarmak için benzer dini olguları kategorize etmektir. ${ }^{4}$ Müslüman âlimlerin araştırmalarında da yer alan dinler tasnifleri din, bilim dalı ve bilim adamı gibi çeşitli unsurlara göre farklılık arz etmektedir. Bu tasniflerin, dinlerin kendi sinıflandırmalarını esas alan normatif tasnif; 5 dinlerin doğduğu veya hâkim olduğu coğrafyalara nispetle yapılan coğrafi tasnif; 6 felsefi argümanlara dayalı felsefi tasnif; ${ }^{7}$ dini fenomenler odaklı fenomenolojik tasnif ${ }^{8}$ ile dinlerin biçimsel yapılarına dayalı morfolojik tasnif gibi çeşitli başlıklar altında toplanabileceği belirtilmektedir. ${ }^{9}$

Dinler Tarihinin tarihsel seyrine bakıldığında günümüzde coğrafi yaklaşımın yaygınlığı ve kullanım kolaylığına rağmen morfolojik yaklaşımın yadsınamaz şekilde cezp ediciliğe sahip olduğu ve konunun ilk defa bu bağlamda belli bir sistematiğe kavuştuğu ve dinamik hale geldiği dillendirilmektedir. ${ }^{10}$ Buradan hareketle bu çalışmada, morfolojik yaklaşımın ilk tezahürlerine göz atarak yaklaşımı dikkate değer ölçüde sistematize eden Din Fenomenolojisinin kurucularından Hollandalı dinler tarihçisi Cornelius Petrus Tiele (1830-1902)'nin konuyla ilgili görüşleri irdelenip dini araştırmalar alanındaki yansımalarına odaklanmak suretiyle

\footnotetext{
3 Şinasi Gündüz, “Giriş”, Yaşayan Dünya Dinleri, ed. Şinasi Gündüz (Ankara: D.İ.B. Yayınları, 2007), 29-30.

4 Charles Joseph Adams, "Classification of Religions", erișim: 01 Aralık 2018, https://www.britannica.com/topic/classification-of- religions.

5 Şehristani ve İbn Hazm gibi Müslüman âlimlerin ilahi ve batıl dinler şeklindeki Kuran merkezli ayrımı esas alarak ortaya koydukları tasnifler bu bağlamdadır. Bk. Günay Tümer, "Din”, Türkiye Diyanet Vakfı İslam Ansiklopedisi (Ankara: TDV Yayınları, 1994), 9: 318.

${ }^{6}$ Dinler tarihi çalışmalarında coğrafya esaslı olarak, Hint, Uzak Doğu, Orta Doğu, Afrika ve Amerika dinleri gibi tasnifler sıklıkla kullanılır. Örneğin dinler tarihçisi Ninian Smart (1927-2001) bu tarz tasniflere yer verdiği The World's Religions (1998) (Dünya Dinleri) adlı eserinin yanı sıra, Religions of Asia (1993) (Asya Dinleri), Religions of the West (1994) (Batı Dinleri) adlı çalışmaları kaleme almıştır.

7 Hegel (1770-1831) ve Schleiermacher (1768-1834) gibi meşhur felsefeciler, Hıristiyanlığın zirvede yer aldığ evrimci bir merdiven yardımıyla dinleri tasnif etmişlerdir. Sharpe, Dinler Tarihi: Tarihsel Bir Anlatı, 37-38.

8 Örneğin dini gelişim fikrine karşı çıkan Gerardus van der Leeuw (1890-1950), uzaklık ve uçuş dini, mücadele dini, sükûnet dini, kargaşa dini, zorlanma ve şekil dini, sonsuzluk ve asketizm dini, hiçlik ve merhamet dini, irade ve itaat dini, görkem ve alçakgönüllülük dini ve sevgi dini şeklinde bir dinler tasnifine başvurmaktadır. Bk. Gerardus Van der Leeuw, Religion in Essence and Manifestation (Princenton, New Jersey: Princeton University Press, 1986), 597- 649.

9 Bk. Partin, "Classification of Religions", 3: 1818-1820; Adams, "Classification of Religions".

${ }^{10}$ Adams, "Classification of Religions".
} 
Amerika ve İngiltere bașta olmak üzere Batı'da dünya dinleri kategorisinin hâkimiyetini yansıtan ve popülerlik kazanan başlıca çalışmalar incelenecektir. Nihayetinde morfolojik yaklaşıma yönelik eleştiriler çerçevesinde yaklaşımın Dinler Tarihi alanındaki konumu ele alınacaktır.

\section{A. Morfolojik Dinler Tasnifinin İlk Tezahürleri}

Geçmişten günümüze dinler tasnifinde normatif yaklaşım hem diğer tasnifler için hareket noktası veya eleştiri aracı/objesi vazifesi görmekte hem de müntesibi olunan dini geleneğin anlayışını yansıtacak şekilde belirleyici roller üstlenmektedir. Çünkü bu yaklaşıma göre dinler, sınıflandırıcıların tarihsel, kültürel ve dini açılardan şekillendirilen normları veya standartları ekseninde tasnif edilmiștir. Buna göre özellikle Yahudilik, Hıristiyanlık ve İslam dinleri başta olmak üzere çeşitli dini inanışlar bağlamında "hak din" ve "batıl din" tasnifi ekseriyetle kullanılır olmuştur. Ancak XIX. yüzyılın sonu ve XX. yüzyılın başına rastlayan dönemde dinin kaynağı ve gelişimi ile ilgili teorilere dayalı olarak yapılan dinler tasnifleri daha az normatif, kısmen morfolojik ve görünüşte bilimsel bir yapıda görünmüştür. ${ }^{11}$ Dinleri belli aşamalardan geçen yapılar olarak ele alan bu sınıflandırmalar, tekâmülcü tasnifler şeklinde tasvir edilmiştir. ${ }^{12}$

Morfolojik yaklaşımın ilk tezahürlerinden birisi, "Primitive Culture, 1871" (İlkel Kültür) adlı eseriyle, dinin en eski șeklinin animizm olduğunu ortaya koyup döneminin evrimci din teorilerinin en tipik örneğini sunan İngiliz antropolog Edward B. Tylor (1832-1917)'dır.13 Tylor aşağı ırklar olarak tanımladığı ilkel kabilelerin inanışlarını tanrı veya ölüm ötesi gibi unsurlar bağlamında incelemenin bu inanışları din kategorisi dışına itmek anlamına geldiğini ve bu bağlamda asgari düzeyde bir din tanımına ihtiyaç duyulduğunu vurgulayarak dini, "ruhsal/manevi varlıklara inanç" şeklinde tanımlamıştır. ${ }^{14}$ Tylor'ın teorisine göre ilkel insanlar, doğa olaylarının oluşumunu manevi varlıklarla açıklamış, bu inanç politeizminin doğmasına yol açmış ve sonrasında tanrıların gücünün tek bir tanrıda toplanmasıyla monoteizm teşekkül etmiştir. Bu şekilde Tylor, evrimciliği esas alan bir

11 Partin, "Classification of Religions", 3: 1818.

12 Mahmut Aydın, Ana Hatlariyla Dinler Tarihi: Tarih, İnanç ve İbadet (İstanbul: Ensar Neşriyat, 2015), 52.

13 Bk. Ninian Smart, The Religious Experience of Mankind (New York: Charles Scribner's Sons, 1969), 71-73.

[358 1 $\quad 14$ Edward Burnett Tylor, Primitive Culture: Researches Into The Development Of Mtyhology, Philosophy, Religion, Art and Custom (London: John Murray, Albemarle Street, 1871), 1: 383. 
dinler tasnifi ortaya koymuştur. ${ }^{15} \mathrm{Bu}$ minval üzere dinin kaynağı ile ilgili ortaya konan ve politeizmden monoteizme geçişi vurgulayan mana, tabu, totemizm ve fetişizm gibi "tabii/doğal" din kategorilerini artıran tekâmülcü teorilerin bir ölçüde morfolojik karakter taşıdıkları düşünülebilir. ${ }^{16}$

Genel itibarıyla morfolojik yaklaşımın ilk tezahürlerini teşkil eden teoriler, evrimsel ölçeklere ve tarafsız olmayan normatif öneme haiz aşamalara dayanır. Bu nedenle eski olanın daha aşağı ve değersiz; daha sonra olanın ise daha yüksek ve üstün olduğu anlayıșı benimsenerek, kronolojiye değer biçici şekilde önem verilir. Monoteizm erişilebilen en yüksek dini aşama olarak görülür. Bütün dinler, büyük monoteist dinlerin en tepede yer aldığı bir ölçekteki konumlarıyla ayırt edilip sınıflandırılır. Aynı zamanda, tüm dinlerin ilkel temelleri ve başlangıçları ortaya çıkarılabilir. Zira evrimciler, dinlerin başlangıç sırlarını ortaya çıkarıp açıklayabileceklerine inanmışlar ve dinin kaynağı ile özünün özdeş olduğunu varsaymışlardır. ${ }^{17}$

Bu süreçte bilimsel metotlara başvurup dinin başlangıcına/kaynağına dair kesin bir şey söylemenin mümkün olmadığı anlayışı hâkim olmakla birlikte, ${ }^{18}$ ortaya konan tekâmülcü tasnifler belli bir dönem din araştırmacılarını etkilemiş, görüşleri üzerinde şekillendirici etkiye sahip olmuş ve kimi zaman onlar için hareket noktası vazifesi görmüștür. XX. Yüzyılın ortalarında kadar Batı'da yazılan Dinler Tarihi kitaplarının birçoğu bu tasnifler doğrultusunda yazılmıştır. ${ }^{19}$ Ancak bu tasnifler, genel anlamda dinin tarihsel süreçte nasıl geliştiğini inceleyip özelde her dini geleneğin kendi tarihi gelişime önem vermeyerek, dinleri anlamada bir kılavuz vazifesi görmek yerine dinlerle ilgili birtakım önyargıların ortaya çıkmasına zemin hazırlamıştır. ${ }^{20}$

\section{B. Morfolojik Dinler Tasnifinin Sistematik Hale Gelişi: Cornelius P. Tiele'nin Dinler Tasnifi ve Alandaki Yansımaları}

XIX. yüzyılın ikinci yarısında özellikle Kraliçe Victoria (1837-1901)

\footnotetext{
15 Bk. Tylor, Primitive Culture, 304-361; Partin, "Classification of Religions", 3: 1818; Baki Adam, "Din Hakkında Genel Bilgiler", Dinler Tarihi El Kitabı, ed. Baki Adam (Ankara: Grafiker Yayınları, 2015), 47-48; Tylor'ın animizmden yüce varlık inancına varan din teorisi hakkında ayrıntılı bilgi için bk. Mustafa Alıcı, Evrimci Politeizm Devrimci Monoteizm: Erken Kültürlerde Yüce Varlık Fikrine Etnolojik ve Fenomenolojik Yaklaşımlar (İstanbul: Rağbet Yayınları, 2013), 109-185.

16 Jonathan Z. Smith, Relating Religion: Essays in the Study of Religion (Chicago, London: The University of Chicago Press, 2004), 188.

17 Partin, "Classification of Religions", 3: 1818-1819.

18 Adam, "Din Hakkında Genel Bilgiler", 44.

${ }^{19}$ Mehmet Aydın, Dinler Tarihine Giriș (İstanbul: Literatürk Academia, 2015), 59.

${ }^{20}$ Aydın, Ana Hatlariyla Dinler Tarihi, 52-53.
} 
dönemi İngiltere'sinde dinle ilgili çalışmalar, Tylor gibi antropologların ait olduğu antropolojik ekol ile mukayeseli çalışmalara vurgu yapan Max Müller (1823-1900)'in başını çektiği tarihi ekolün etkisi altındaydı. ${ }^{21}$ Bu süreçte antropologlar tarafından ileri sürülen tekâmülcü din teorileri Dinler Tarihinin kurucularının gündeminde yer almış ve onların din ve dinlerin tasnifleri ile ilgili görüşlerinin şekillenmesinde yönlendirici olmuştur. Nitekim Dinler Tarihinin bir disiplin olarak oluşumunda kilit rol oynayan Alman asıllı filolog Müller, dinleri anlamak için dinler tasnifinin önemini “Tasnif et ve fethet!" sözüyle özetlemiştir. ${ }^{22}$

Evrimci antropologların kabullerinin bir kısmının yersiz olduğunu ${ }^{23}$ ve din tasniflerinde kullanılan hak-batıl, ilahi-tabii gibi din ayrımlarının bilimsel açıdan değersizliğini savunan Müller, dil araştırmalarından hareketle dinleri tasnif etmiştir. ${ }^{24}$ Çünkü o, diller arasında bir genetik bağ olduğu için dillerin belli dil aileleri olarak tasnif edilebileceği gibi dinlerin de bağlı oldukları dil aileleri bağlamında sınıflandırılabileceğini düşünmüştür. Keşfedilen dil ailelerine göre dünya dinlerini, Semitik (Yahudilik, Hıristiyanlık ve İslam), Aryan (Hinduizm, Budizm vb.), Turan (Türk, Moğol halk dinleri vb.) ve Çin (Konfüçyüs vb.) dinleri olarak tasnif etmiştir. ${ }^{25} \mathrm{Bu}$ şekilde ırka ve genetiğe dayalı olarak dinleri tasnif eden Müller, dini fenomenleri ihmal etmesine rağmen ${ }^{26}$ dinler tasnifine belli ölçüde ivme kazandırmıştır. ${ }^{27}$

Bu bağlamda Dinler Tarihinin babası olma konusunda Müller'in rakibi ${ }^{28}$ ve Kita Avrupa'sında muadili kabul edilen Tiele, ${ }^{29}$ gelişimci din anlayışına dayanan morfolojik dinler tasnifiyle çeşitli din bilimcilerini etkileyen ve alandaki çalışmalara yön veren görüntüsüyle ön plana çıkmaktadır. Tiele, kendi döneminde dini araştırmalarda yaygın şekilde kullanılan gelişme kavramını ve onun etrafında şekillenen hipotezleri

21 Mustafa Alıcı, Dinler Tarihinin Batılı Öncüleri (İstanbul: İz Yayıncılık, 2011), 103.

22 Max Müller, Introduction to the Science of Religion (London: Longmans, Green, and Co., 1882), 68-82.

23 Sharpe, Dinler Tarihi: Tarihsel Bir Anlatı, 62.

24 Sharpe, Dinler Tarihi: Tarihsel Bir Anlatı, 63.

25 Müller, Introduction to the Science of Religion, 90-94; Alıcl, Dinler Tarihinin Batıll Öncüleri, 67; Partin, "Classification of Religions", 3: 1818; İbrahim Ethem Karataş, Max Müller: Hayatı, Eserleri ve Dinler Tarihindeki Yeri (Doktora Tezi, Dokuz Eylül Üniversitesi, 2006), 68.

26 Alıcı, Dinler Tarihinin Batılı Öncüleri, 67.

27 Partin, "Classification of Religions", 3: 1818.

28 Sharpe, Dinler Tarihi: Tarihsel Bir Anlatı, 54.

${ }^{29}$ Sharpe, Dinler Tarihi: Tarihsel Bir Anlatı, 148. 
incelemiş ve dinin gelişimi ile ilgili görüşler ortaya koymuştur. ${ }^{30}$ Ona göre din, yaşayan organizmalar gibi doğum, büyüme, gelişme ve yok olma gibi birtakım aşamalardan geçer ve kısa veya uzun ömürlü olabilir. Ancak her şeye rağmen değișen ve değişmeyen özellikleriyle insanlığın hayatında sonsuza kadar var olacaktır. ${ }^{31}$ Tiele, "Elements of the Science of Religion"32 (Din Biliminin Öğeleri) adlı Gifford derslerinde görüşlerini sistematik tarzda açıklamıştır. Dinin morfolojik yönüne dair 1896'daki dersinde dinin değişen öğelerini; dinin ontolojik yönüne dair 1898'deki dersinde dinin değişmeyen yönü olarak dinin özünü incelemiştir. Bu dersler Tiele'nin Dinler Tarihi anlayışının özünü oluşturmaktadır. ${ }^{33}$

Dini, farklı dinlere işaret edecek şekilde ayrı fenomenler olarak değerlendirmek yerine genel bir din olgusundan bahseden Tiele, dinin psikolojik bir fenomen olarak farklı ırklar ve halklar arasında tezahür ettiğini ifade eder. Outlines of the History of Religion kitabındaki "History of Religion" (Din Tarihi) isimlendirmesi bu anlayışı yansıtır. ${ }^{34}$ Ona göre din insanlığın evrensel fenomenlerinden biridir ve belli aşamalardan geçmektedir. ${ }^{35} \mathrm{Bu}$ nedenle Dinler Tarihinin temel görevi dinin evrimsel gelişim süreçlerini ortaya koymaktır. ${ }^{36}$

Dinlerin morfolojik ve ontolojik yönlerine dikkat çekerek, dinleri bir bütün halinde ve her türlü önyargıdan arındırılmış zihinlerle incelemeyi öneren Tiele, Dinler Tarihinin bilimsellik özelliğini kazanabilmesi için karşılaştırmalar yapmayı şart koşar. Bu nedenle dinleri morfolojik tarzda tasnif edip karşılaştırmalar yapmayı ve dinlerin diğer dinlerle benzerliklerini ve farklılıklarını ortaya koymayı amaçlamaktadır. Illk olarak döneminde öne çıkan dinler tasniflerini değerlendirmeye tabi tutan Tiele, Müller'in hak-batıl, ilahi-tabii ve düalist-politeist-monoteist şeklindeki tasnifleri kullanışsız ve mantıksız görmesine hak verirken, dil ailelerinden hareketle dinler tasnifine itiraz eder. Çünkü Tiele, Müller'in dil aileleri ve genetik dinler tasnifini özdeş kabul etmesinin, erken dönemler için kabul edilebilir olsa da tarihi süreçte

\footnotetext{
30 Arie L. Molendijk, "Religious Development: C.P. Tiele’s Paradigm of Science of Religion”, Numen 51/3 (2004): 321-322.

31 Cornelius P. Tiele, Elements of the Science of Religion: Part I. Morphological (Edinburgh: William Blackwood and Sons, 1898), 30.

$32 \mathrm{Bu}$ dersler Elements of the Science of Religion: Part I. Morphological (1897) ve Elements of the Science of Religion: Part II. Ontological (1898) adıyla kitaplaştırılmıștır.

33 Molendijk, "Religious Development: C.P. Tiele's Paradigm of Science of Religion", 336.

34 Tiele, Outlines of the History of Religion to the Spread of the Universal Religions (London: Kegan Paul, Trench, Trübner, 1896), VII-XI; Alıcı, Dinler Tarihinin Batılı Öncüleri, 116-119.

35 Tiele, Outlines of the History of Religion, 6.

36 Tiele, Elements of the Science of Religion: Part I. Morphological, 10
} 
dinin dilden ve etnik kökenden bağımsız hale geldiğini belirterek, bir dinin gelişim aşamasında taraftarlarının dillerinin açık bir etkisinin olmadığını ve bilimsel tarzdaki morfolojik sınıflandırmalarla bunun anlaşılabileceğini ifade eder. ${ }^{37}$

Bilimsel anlamda morfolojik bir tasnife ulaşmak amacıyla daha önce yapılmış çalışmalardan yararlanmanın gerekliliğine inanan Tiele, Amerikan filolog ve felsefeci William D. Whitney (1827-1894)'in dinler tasnifinden etkilenmiş görünmektedir. "Dinler arasında, dil gibi bir toplumun bilgeliğinin müşterek ürünü olan ve nesilden nesile kasıtsız nakledilen soy dini ile tek bir kurucu tarafindan şekillendirilen din arasındaki ayrımdan daha belirgin bir ayrım yoktur" anlayışı çerçevesinde dinleri, "soy dini" ve "kurulmuş din" olmak üzere ikili tarzda tasnif eden Whitney, Zerdüştilik, Muhammedanizm [İslam], Budizm ve Hıristiyanlığı birinci, Yahudiliği ikinci din kategorisinde değerlendirmiştir. ${ }^{38}$

Whitney'in tasnifinin dinlerin tabiat ve ahlaki yönlerini vurgulamasına olumlu yaklaşan ancak genel olarak yalnızca dinler arasındaki derece farklılığını ortaya koyduğunu, dolayısıyla dinler arasındaki mahiyet farklılıkları ve onların temel türlerini anlamada yeterli olmadığını belirten Tiele, yine de onun tasnifi ile ilişkilendirilebilen "tabiat" (natural) dinleri" ve "ahlaki" (ethical) dinler" şeklinde ikili tarzda morfolojik bir tasnif yapmış ve gelişimci din anlayışını yansıtacak şekilde bunları alt başlıklara ayırmıştır. ${ }^{39}$ Konuya ilk defa Outlines of the History of Religion (1876) adlı eserinde temas eden Tiele, Encyclopedia Britannica (1885) için yazdığı "Religions" (Dinler) maddesinde görüşlerini ayrıntılı şekilde açıklamıştır. ${ }^{40}$

Tiele'ye göre tabiat dinleri, tabiatçı özellikleri ağır basarken ahlaki ilkelere asgari düzeyde yer veren en eski inançlardır. İnsanın yaşamını kontrol edemediği, kaderinin insanüstü güçlerle donatılmış hayvanlar, canavarlar ve uğursuz mitolojik yaratıklar gibi çeşitli varlıklar tarafından tayin edildiği inancını vurgulayan ve dinin ilk aşamasını teşkil eden bu dinler, en aşağıdan en yukarıya doğru ilkel ve vahşi toplumların dinleri gibi "polidemonistik büyüsel dinler" (animizm), Arap veya Japon dini gibi "saflaşmış ve organizeli büyüsel dinler" (therianthropic politeism) ve Zerdüşt öncesi

37 Tiele, Elements of the Science of Religion: Part I. Morphological, 8; "Religions", 20: 358359.

38 Bk. William D. Whitney, “On the So-Called Science of Religion”, Princeton Review 57/1 (1881): 429-452.

39 Tiele, "Religions", The Encyclopedia Britannica (Edinburgh: Adam and Charles Black, 1886), 20: 358-371; Outlines of the History of Religion, 12.

40 J. Z. Smith, Relating Religion: Essays in the Study of Religion, 189. 
İran dini gibi "insanüstü ve yarı ahlaki insan benzeri varlıkları ilahlaştıran dinler" (antropomorphic polyteism) olmak üzere üç üyeli bir ailedir. ${ }^{41} \mathrm{Bu}$ dinler ahlaki özellikler taşısalar da mitolojilerinde yer aldığı üzere tanrıların bir takım ahlaki düşüklükleri nedeniyle kendilerini gerçek bir ahlak anlayışına sahip olarak sunmazlar. ${ }^{42}$

Tiele'nin kendisini takiben ortaya çıkan morfolojik dinler tasniflerini önemli ölçüde etkileyen ahlaki dinler kategorisi, "nomistik (genel ilke ve yasalar koyucu) milli dinler" ve "evrensel dinler/dünya dinleri" şeklinde iki üyeli bir ailedir. Nomistik milli dinler, yalnızca bir insanın anlayışıyla sınırlanmış, kutsal metne dayanan bir yasa etrafında şekillenen dinleri ihtiva eder. Bunlar, Taoizm, Konfüçyanizm, Brahmanizm, Caynizm, İlkel Budizm, Mazdeizm, Musevilik (Mosaism) ve Yahudilik (Judaism) ${ }^{43}$ dinleridir. Bir milletin/toplumun menfaatlerini gözeten nominist karakterdeki dinlerin aksine bütün insanlığın menfaatini esas alıp dinlerini yayma amacı ve manevi ahlaki normlar taşıyan ve bu nedenle nominist dinlerden daha üst bir konumda yer alan evrensel dinler/dünya dinleri İslam, Budizm ve Hıristiyanlık şeklinde üç üyeli bir aile formundadır. Yahudilik, evrensel dinler yönüne doğru geçiş sürecindedir. Tiele'ye göre Budizm ve Hıristiyanlığın tam anlamıyla evrensel kabul edildiği dünya dinleri eşit düzlemde değildir. Çünkü orijinal ve olgun olmayan İslam, Yahudilik ve Hıristiyanlığın yabani bir filizidir ve dış özellikleri açısından Yahudilikten bir parça daha iyidir. Tanrıyı ihmal eden ateist kökenli Budizm, çok fantastik mitoloji ve en çocukça batıl inançlardan oldukça etkilenmiştir. Hıristiyanlık manevi karakteri gereğince yalnızca ruhsal yönden tapınmayı telkin etmesinden ötürü rakipleri karşısında kıyaslanamayacak derecede üstün konumdadır. Böylece bir teolog tavrı sergileyen Tiele, her ne kadar "Biz burada ne bir inancl itiraf ediyor ne de bir inanç savunması yapıyoruz" diyerek analizlerinin bilimsel olduğunu iddia etse de dinleri karşılaștırarak dinin genel yapısını kavramak yerine Hıristiyanlık yanlısı apolojik yaklaşımdan kurtulamamıştır. ${ }^{44}$

Genel itibarıly Tiele'nin dinler tasnifinde, "daha yüksek" ve "daha düşük" dinleri ayırt etmede, yeni ve belirleyici bir vasıta olarak ahlaka

41 Tiele, "Religions", 20: 367-368; Outlines of the History of Religion, 12; J. Z. Smith, Relating Religion: Essays in the Study of Religion, 190.

${ }^{42}$ Adams, "Classification of Religions".

43 Tiele Yahudiliği, Musevilik ile İbrani kutsal metnine dayanan dini; Yahudilik ile Rabbani Yahudiliği kastederek iki ana kategoriye ayırmaktadır. Alıcı, Dinler Tarihinin Batılı Öncüleri, 138.

44 Tiele, "Religions", 20: 368-369; J. Z. Smith, Relating Religion: Essays in the Study of 
yönelik vurgusu, kendi döneminde dini araştırmalar alanında sıklıkla kullanılan bir argüman haline gelmiştir. Ancak tek tanrılı dinlerin ahlak ve ahlakiliği vurguladığı doğru olmakla birlikte, ilkel dinler olarak isimlendirilen dinlerde ahlâk kaygısının mutlak anlamda yokluğundan söz edilemeyeceği için Tiele'nin ve onun görüşlerini benimseyen çağdaşlarının değerlendirmeleri ilkel insanların dini inançlarını anlamaktan ziyade onlara dair önyargıları yansıtmaktan öteye geçememiştir.45

Ancak ortaya koyduğu dinler tipolojisiyle döneminde belli bir popülariteye kavuşan Tiele, Dinler Tarihinin batılı öncülerinin görüşleri üzerinde önemli etkilere sahiptir. Bunların başında kutsal kavramını Dinler Tarihi çalışmalarına uygulamada önemli katkılar sunan Nathan Söderblom (1866-1931) ve Mircea Eliade (1907-1986) gelmektedir.

İsveçli dinler tarihçisi Söderblom, daha yüksek dinleri "kültür dinleri" ve "vahye/peygambere dayalı dinler" şeklinde ikiye ayırıp özelliklerini betimlemek amacıyla bir terminoloji geliştirmiştir. Buna göre kültür dinlerinin en yüksek seviyesi "sonsuzluğun mistisizmi" olarak, Hindu ve Budist dini tecrübesinde; vahiy dinlerinin zirvesi "kişiselliğin mistisizmi" şeklinde Zerdüștilik, Musevilik ve Hıristiyanlıkta bulunmaktadır. Bu ayrımlar Tiele'ye pek çok şey borçlu olmasına rağmen Söderblom, Tiele'nin din tarihindeki gelişim tezine karşı durmaktadır. Çünkü ona göre aralarında derin ve aşılmaz uçurum bulunan tabiat dini ile vahye/peygambere dayanan din, tarihi süreçte birinin diğerine evriminin söz konusu olamayacağı kadar farklıdır. Diğer taraftan vahye/peygambere dayanan dini, radikal ve tamamen yeni bir müdahale olarak açıklayan Söderblom, bunları kültür dinlerinden üstün tutmuş ve bütün dinleri son vahiy dediği Hıristiyanlığa göre değerlendirmiştir. Zira seçkin bir dinler tarihçisi olduğu kadar bir teolog ve din adamı kimliğine sahip olan Söderblom, bilimsel ve tarihi çalışmalarının Hıristiyanlığın yegâneliğini ve üstünlüğünü teyit eden objektif bir temel sunduğuna inanmıștır. ${ }^{46}$

Söderblom'un fikirlerinden önemli ölçüde istifade eden Romen asılll, dönemin etkili ve üretken dinler tarihçisi Eliade dinleri Asya, Avrupa ve Amerika medeniyetlerin arkaik kültleri ile ilkel dinleri içeren arkaik "geleneksel (kozmik) dinler" ve Yahudilik, Hıristiyanlık ve İslam gibi arkaik sonrası "tarihi dinler" olmak üzere iki kategoride incelemektedir. Bu ayrımda

45 Partin, “Classification of Religions”, 3: 1818.

|364| 46 Bk. Adams, “Classification of Religions"; Alıcı, Dinler Tarihinin Batılı Öncüleri, 332-335 Sharpe, Nathan Söderblom and The Study of Religions (London: University of North California, 1990), 111. 
dinlerin zamansal özelliklerini ve dünyaya bakışlarını esas alan Eliade'ın değerlendirmelerine göre geleneksel bütün dinler, özellikle tarihsel zamana karşı başkaldırma, sıradan ve profan (dindışı) zamanı reddetme bakımından ortak bir dünya görüşünü paylaşır. İnananların eylemleri başlangıca (illud tempus) veya büyük zamana dönüş için tekerrür eden teşebbüslerdir ve kutsallar, arketiplerle ilişkilendirildiği için mitolojik ve döngüsel zaman anlayışı dinlerin en belirgin özelliğidir. Tarihi dinlerde ise tanrı ile dünya arasında başlangıç ve son şeklinde kesintilerin olduğu doğrusal zaman anlayışı hâkimdir. Mitler kutsal bir tarih olarak algılanır ve kutsal, tarihi olaylarda tezahür eder. Monoteist özelliğe sahip Yahudilik, Hıristiyanlık ve İslam bu kategoride yer almakla birlikte, Doğu Avrupa'nın kozmik Hıristiyanlığında olduğu gibi bir dinin farklı iki kategorinin özelliğini barındırdığı durumlar da söz konusudur. ${ }^{47}$ Eliade, özellikle geleneksel dinlerle ilgili açıklamaları ile dinler tasnifi çalışmalarını ileri bir aşamaya taşımayı başarmakla birlikte, dinler kategorilerine dâhil ettiği dinler bakımından Tiele ve Söderblom ile benzer noktada durmaktadır.

Tiele'nin morfolojik dinler tasnifi yaklaşımı bağlamında dini araştırmalar alanına en büyük katkısı ise kendisinden daha önce farklı dillerde kullanılan "dünya dinleri" ${ }^{8}$ kavramının İngilizcenin hüküm sürdüğü akademik çevrelerde yaygınlaşmasına kapı aralaması ve konuyla ilgili farkındalığı artırmasıdır. Tiele'nin öğrencisi Chantepe de la Saussaye (18481920) bu kavramın ilk defa Alman teolog Johann Sebastian von Drey (17771853) tarafından kabaca "Bir Millet Dini ve Dünya Dini Üzerine" şeklinde tercüme edilebilecek "Von der Landesreligion und der Weltreligion" (1827) adlı Almanca makalesinde yegâne dünya dininin Hıristiyanlık iken pagan kültüre ait dinlerin milli karakter taşıdığını vurgulamak için kullanıldığını belirtmiştir. Von Drey ile başlayan bu süreçte özellikle 1870 ve 1880 'li yıllarda Almanca ve Felemenkçe konuşulan çevrelerde hangi dinin dünya dini veya milli din olduğuna yönelik çeşitli tartışmalar ortaya çıkmıştır. Bu dönemde Budizm ile ilgili orijinal çalışmaların etkisiyle Hıristiyanlıkla beraber Budizm de dünya dini kabul edilmiş ve İslam'ın konumuyla ilgili din bilimcileri farklı görüşler serdetmişlerdir. Tiele, Encyclopedia Britannica (1885) için yazdığı "Religions" maddesinde, asıl itibarıyla Felemenkçe

47 Bk. Mircea Eliade, Ebedi Dönüş Mitosu, çev. Ümit Altuğ (Ankara: İmge Kitabevi, 1994); Adams, "Classification of Religions"; Partin, "Classification of Religions", 3: 1821.

48 Tiele'nin, İngilizceye Outlines of the History of Religion to the Spread of the Universal Religions adiyla çevrilen eserinde yer alan "Universal Religions" (evrensel dinler) ifadesi, eserin "Geschiedenis van den godsdienst tot aan de heerschappij der Wereldgodsdiensten" adlı Felemenkçe orijinalinde "wereldgodsdiensten" (dünya dinleri) şeklindedir. Bk. Molendijk, “Religious Development: C.P. Tiele's Paradigm of Science of Religion”, 330. 
"wereldgodsdiensten" ve Almanca "weltreligionen"ın literal anlamını ifade eden "dünya dinleri" (world religions) kavramını vurgulamak suretiyle, İngilizcenin hâkim olduğu ve bu tarz kategorilerin etkin olmadığı akademik dünyada kullanılmasına önderlik etmiştir. Bu doğrultuda bu kavramın, "evrensel dinler" veya -Tiele'nin zaman zaman tercih ettiği- "evrenselci dinler" şeklinde de kullanıldığı ve ilk zamanlarda Von Drey ile benzer şekilde Hıristiyanlığın öteki dinler karşısındaki üstünlüğünü vurgulama amacı taşıyan Amerikan din bilimcisi William Fairfield Warren (1833-1929) imzalı, "The Religions of the World and the World-Religion, 1892" (Dünya Dinleri ve Dünya Dini) örneğinde olduğu gibi çeşitli çalışmaların kaleme alındığı bir süreç başlamıștır. ${ }^{49} \mathrm{Bu}$ durum Tiele'nin, modern dönemde Amerika'da akademik faaliyetlerini sürdüren Japon asıllı Tomoko Masuzawa ve İskoç asıllı James L. Cox gibi çeşitli din bilimcilerinin dinlerin batılı bilim adamları tarafından belli başlı dinler ekseninde incelenmesini ifade etmek amacıyla ortaya koydukları morfolojik karakterli "dünya dinleri görüşü" veya "dünya dinleri paradigması" anlayışının öncüsü kabul edilmesine yol açmıştır. ${ }^{50}$

\section{Morfolojik Dinler Tasnifinde Dünya Dinleri Paradigmasının Egemenliği}

Tiele'nin İngilizce konuşan dünyaya tanıttığı dünya dinleri kavramı bilimsel olarak takip edilebilir nitelikte olmasına ve normal kitle iletişim araçlarında sıklıkla kullanılmasına rağmen üzerinde ittifak edilen bir anlam yapısına sahip değildir. Öyle ki bu kavram farklı zaman ve mekânlarda üç ayrı anlama sahip olacak şekilde kullanılmıştır. Bunlar; en geniş anlamıyla, dünyanın herhangi bir yerinde hali hazırda mevcut olan dinleri ifade etmesi (1); daha dar ve değer biçici tarzda, bir bölgenin veya milletin sınırlarını aşan dinlerin dünyanın büyük dinleri şeklinde nitelendirildiğine işaret etmesi (2) ve akademik çevrelerde yaygın şekilde kullanılan bir kitabın veya çalışmanın başlığının, içeriğin yalnızca Hıristiyanlık veya Yahudi-Hıristiyan gelenekle sınırlandırılmadığını ve pek çok dinin de araştırmaya dâhil edildiğini

49 Tomoko Masuzawa, "World Religions", Encyclopedia of Religion (Second Edition), ed. Lindsay Jones (New York: Macmillan Reference, 2005), 14: 9802; Chantepie de la Saussaye, Manual of the Science of Religion (London: Longmans, Green and Co., 1891), 54. 50 Masuzawa'nın, The Invention of World Religions (2005) adlı eseri, dünya dinleri kavramı üzerinden dini araştırmalardaki Batı hegemonyasına ve oryantalist bakıș açısına yönelik önemli bir eleștiri niteliği taşımaktadır. Bk. Tomoko Masuzawa, The Invention of World Religions: Or, How European Universalism Was Preserved in the Language of Pluralism (Chicago, London: The University of Chicago Press, 2005). James L. Cox ise Masuzawa'nın görüşlerinden hareketle dini araştırmalarda çeşitli tasniflere başvurmak yerine dini yeniden tanımlamak gibi yeni yaklaşımlara duyulan ihtiyacı vurgulamaktadır. Bk. James L. Cox, From Primitive to Indigenous: The Academic Study of Indigenous Religions (Hampshire, Burlington: Ashgate, 2007), 33-52. 
vurgulamasıdır (3). ${ }^{51} \mathrm{Bu}$ anlamları kapsayacak şekilde XX. yüzyılın başlarından itibaren dini araştırmalarda her ne kadar bazı bireysel farklılıklar, eklemeler, çıkarmalar, bölünmeler ve birleștirmeler söz konusu olsa da standart ve geleneksel bir dünya dinleri listesinin teşekkül ettiğini söylemek mümkündür. Bu doğrultuda Hıristiyanlık, Budizm, İslam, Hinduizm ve Yahudilik bu listenin daimî üyesi iken, Konfüçyanizm, Taoizm, Şintoizm, Caynizm, Sihizm ve Zerdüştilik sıklıkla bu listenin içerisinde yer almıştır. ${ }^{52} \mathrm{Bu}$ itibarla özellikle II. Dünya savaşından sonraki süreçte dünya dinleri kavramı bağlamında kaleme alınan çalışmalar İngilizce konuşulan dünyada oldukça popüler hale gelmiş ve eğitim kurumlarında öğrencilerin anlam dünyalarını şekillendiren bir yapıya bürünmüştür. Bu bağlamda Amerika ve İngiltere'de dünya dinleri paradigmasının egemenliğine katkı sağladığı -özellikle James L. Cox tarafından- ifade edilen başlıca çalışmaları ve genel özelliklerini ele almak konuyu anlaşılır hale getirmektedir.

Amerika'ya bakıldığında 1920'li ve 1930'lu yıllarda eğitim müfredatında dünya dinleri paradigmasına işaret eden örneklerin kullanılmaya başlamasını bir dönüm noktası olarak ifade eden Masuzawa, bu dönemde bu tarz çalışmaların sayısının önemli ölçüde arttığına dikkat çekmektedir. ${ }^{53} \mathrm{Bu}$ bağlamda dinler tarihçisi ve misyolog Robert Ernest Hume (1877-1949)'un "The World's Living Religions, 1924" (Yaşayan Dünya Dinleri) adlı eserini bir numune olarak değerlendirmek mümkündür. Zira Hume ortaya çıktıkları coğrafyalara göre dinleri, Güney Asya Kökenli Dinler (Hinduizm, Caynizm, Budizm, Sihizm), Doğu Asya Kökenli Dinler (Konfüçyanizm, Taoizm, Şintoizm), Batı Asya Kökenli Dinler (Yahudilik, Zerdüştilik, İslam, Hıristiyanlık) şeklinde on bir dini ihtiva eden dört kategori altında incelemiştir. Dinler arasında karşılaştırmalar yapan Hume, bu şekilde Hıristiyanlığın diğer dinler arasında gerçek anlamda bir dünya dini olarak özellikle tanrı inancı bağlamında- temayüz ettiğine yönelik bir temel sunmaya çalışmıştır. ${ }^{4}$ Genel itibarıyla bu ve benzeri eserler, ${ }^{55}$ günümüzde akademik ve genel çevrelerde oldukça popüler hale gelen dünya dinleri kavramının eleștirilmeden kabul edilişinin ilk örneklerini sunmaktadır. ${ }^{56}$

51 Masuzawa, "World Religions", 14: 9800.

52 Masuzawa, "World Religions", 14: 9803.

53 Masuzawa, The Invention of World Religions, 37.

54 Bk. Robert Ernest Hume, The World's Living Religions (New York: Charles Scribner's Sons, 1924).

55 Cox, From Primitive to Indigenous, 34.

56 Örneğin karşılaştırmalı din profesörü Amerikan John Clark Archer (1881-1957), Faiths Men Live By (1934) adlı eserinde dünya dinleri paradigmasında söz konusu edilen on bir din ile birlikte dünyada halen mensubu bulunan ilkel kabile dinlerini incelemiş ve sonuç 
Amerika'da 1950'li yıllardan sonra Amerikan din bilimcisi John B. Noss (1896-1980)'un “Man's Religions, 1949" (İnsanoğlunun Dinleri) adlı eseri hem eğitimde hem de akademide oldukça popüler ve etkin olmuştur. ${ }^{57} \mathrm{Bu}$ çalışmanın 1990 yılındaki sekizinci baskısı yazarın kardeşi olan ve başyazar olarak tayin edilen David Noss (1920-) tarafından dinlerin kadın anlayışı gibi modern konuları da dâhil edilmek suretiyle "A History of the World's Religions" (Dünya Dinlerinin Tarihi) adıyla basılmıștır. ${ }^{58}$ Noss kitabın önsöz kısmında bu şekilde bir çalışmayı kaleme alma amacının dünya dinleri hakkında orijinal kaynaklara dayalı deskriptif tarzda ayrıntılı bilgiler sunmak ve insanların tarih boyunca tabi oldukları başlıca inançların kökenine varan bir tarihi gelişimi ortaya koymak olduğunu belirtmiştir. Bir taraftan döneminde dinler hakkında bilgi veren önemli çalışmaların mevcut olduğuna dikkat çekerken, diğer taraftan bu eserlerin dinlerin güncel durumunu ortaya koymada yetersiz kaldığını vurgulayan Noss, temel amacının dinlerin kuruluşu ile güncel durumları arasında bir köprü kurmak olduğunu dile getirmiştir. ${ }^{59}$

Noss, dünya dinlerini, "İlkel ve Geçmiş Dinler" dışında Hint Dinleri (Hinduizm, Caynizm, Budizm, Sihizm), Uzak Doğu Dinleri (Taoizm, Konfüçyanizm, Şintoizm) ve Yakın Doğu Dinleri (Zerdüştilik, Yahudilik, Hıristiyanlık, İslam) şeklinde coğrafi tarzdaki dörtlü kategoriye göre ele almış ve özellikle dinlerin hem erken hem de sonraki süreçlerine temas etmeye özen göstermiştir. Kitabın üçüncü baskısında kapsamlı bir revizyon yapan Noss, dinler hakkında daha ayrıntılı bilgilere yer vermiş ve kendi dönemindeki antropolojik verilerden yararlanmayı ihmal etmemiştir. Eserinin üniversite derslerinde okutulma isteğini açık şekilde belirten Noss, kapsam genişliğinden ötürü konular arasında seçim yapılabileceğini ifade etmiştir. ${ }^{60}$ Nitekim 2011'de sosyal çatışmalar ve uluslararası gerginliklerde dinin rolünü de irdeleyen on üçüncü baskısıyla bu kitap, halen Amerikan üniversitelerinde öğrenciler ve öğretmenler için kaynak niteliği taşımakta ve derslerde okutulmaktadır. ${ }^{61}$

bölümünde yaptığı karşılaștırmayla dinin, insanın/insanlığın mutluluğuna hizmet etmesi gerektiğini ortaya koymuștur. Bk. John Clark Archer, Faiths Men Live By (New York: The Ronald Press Company, 1934).

57 Cox, From Primitive to Indigenous, 34.

58 Bk. David S. Noss- John B. Noss, A History of the World's Religions (New York: Macmillan, 1990).

59 John B. Noss, Man's Religions (New York: The Macmillan Company, 1949), IX.

60 John B. Noss, Man's Religions (New York: The Macmillan Company, 1963), IX-X.

61 Bk. David S. Noss- Blake R. Grangaard, A History of the World's Religions (New Jersey: Pearson Higher Education, 2011), I-II. 
Cox’a göre Amerika akademisinde ve eğitiminde dünya dinleri paradigmasının yaygınlaşmasında Noss'un etkisine karşıllk, genel okuyucu kitlesini muazzam şekilde etkileyen kişi 1958 tarihli ilk baskısı "The Religions of Man" (İnsanoğlunun Dinleri) adıyla yayınlanan, sonrasında "The World's Religion, 1991" (Dünya Dinleri) adını alan çalışmasıyla karşılaştırmalı din uzmanı Huston Smith (1919-2016)'dir.62 Bu eserinin etkisi nedeniyle dini araştırmalar profesörü Richard D. Hect; Smith'i, Ninian Smart (1927-2001) ve Joseph Campell (1904-1987) ile birlikte genel okuyucu kitlesine hitap eden XX. Yüzyılın ikinci yarısının en büyük üç din bilimcisinden biri kabul etmektedir. ${ }^{63}$

Dine evrensel bir fenomen olarak yaklaşıp onun gücünü ve modern dönemde etkisini ortaya koymayı kitabının amacı olarak belirleyen Smith, Hinduizm, Budizm, Konfüçyanizm, Taoizm, Yahudilik, Hıristiyanlık ve İslam olmak üzere yedi dinin, tarihi ve metin odaklı olmaksızın derin anlamlarını ortaya koyma gayretindedir. 0 , dini anlamanın, tarihi gerçeklikten ziyade anlam sorunuyla ilgili olduğunu ${ }^{64}$ düşündüğü için incelediği dinlerin derin anlamlarını inananlarının bakış açısı etrafında kavramaya çalışmıştır. $\mathrm{Bu}$ anlayış çerçevesinde kitabın her bölümünde söz konusu ettiği dinin ve din kurucularının genel bir panoramasının sunan Smith, din kurucularını insanlığa/insanlara ciddi şekilde yardım etme arzusu taşıyan iyi kimseler olarak nitelendirmiştir. Smith zaman zaman dinlerin tarihlerine temas etmesine rağmen özel olarak bu tarihlerle ilgilenmemiş, bunun yerine önemli teolojileri ve kutsal ritüelleri modern ve liberal kitlelere hitap edecek şekilde tartışmayı tercih etmiştir. ${ }^{65} \mathrm{Bu}$ özellikleriyle elli baskıya ulaşan ve milyonlar satan bu kitap Amerika'da genel okurlar üzerinde oldukça etkili olmuş ve Smith'in televizyon ekranlarında boy göstermesiyle popülerlik kazanmıştır.

İngiltere'ye bakıldığında dünya dinleri paradigmasının egemenliğini dinler tarihçileri Ernest Edward Kellet (1864-1950) ve Alan Coates Bouquet (1884-1976)'in eserleri bağlamında anlamak mümkündür. "A Short History of Religions, 1933" (Dinlerin Kısa Tarihi) adlı eserinin önsözünde,

\footnotetext{
62 Cox, From Primitive to Indigenous, 35.

63 Douglas Martin- Dennis Hevesi, "Huston Smith, 'Author of the Worlds Religions', Dies at 97", erişim: 12 Ocak 2019, https://www.nytimes.com/2017/01/01/us/huston-smithauthor-of-the-worlds-religions-dies-at-97.html.

64 Huston Smith, The World's Religions: Our Great Wisdom Traditions (New York: Harperone, 1998), 1-11.

65 Tara Baldrick-Morrone v. dğr., "Not a task for amateurs: Graduate instructors and Critical Theory in the World Religions classroom", After World Religions: Reconstructing Religious Studies, ed. Christopher R. Cotter, David G. Robertson (London, New York: Routledge, 2016), 41.
} 
çalışmasının amacının din ile ilgilenen kimseleri tatmin etmek değil onların ilgilerini artırmak olduğunu vurgulayan Kellett, dünyada dinin önemi hakkında bir uyanışın olduğunu, insanların onun hakkında düşündüğünü ve bu eylemi hakkıyla gerçekleştirmenin yolunun dini yaşamın tarihi gelişimini bilmekten geçtiğini ifade eder. Mutlak tarafsızlığın mümkün olmadığını düşünen Kellett'in, din kurucularıyla düşman değil arkadaş olmaya çalıştığını belirtmekle sempatik bir yaklaşım arzusuyla hareket ettiği söylenebilir. ${ }^{66}$ Ancak Kellett, Yahudilik, Muhammedanizm [İslam], Hinduizm, Budizm, Caynizm, Taoizm, Konfüçyanizm'i incelemekle birlikte çalışmanın büyük bölümünde İngiliz ve İskoç Kiliseleri ile çeşitli Hıristiyan mezhepleri bağlamında Hıristiyanlıktan bahsetmiştir. Buna rağmen sonuç kısmında, muhtaçlara yardım ve ümit sunma konusunda din kurucularının -özellikle İsa ve Buda- benzer tavırlar sergilediğini belirten ve onlara minnettarlığını ifade eden Kellett, çalışmasının okurları bütün hakikatin kendilerine ait olduğunu düşünmekten kurtarma ihtimalini şahsı adına büyük bir kazanç olarak değerlendirmektedir. ${ }^{67}$ Sonuç itibarıyla Kellett, akademik açıdan sağlam bir temele sahip olan bu çalışmasıyla dinler hakkında ayrıntılı bilgisi bulunmayan ciddi okurlara bilimsel bir Dinler Tarihi yaklaşımı sunmayı hedeflemiş, bu şekilde popüler bir çekiciliğe ulaşmış ve Huston Smith'in Amerika'da yaptığı tarzda dünya dinleri paradigmasının İngiltere'de yaygınlaşmasında etkin olmuştur. ${ }^{68}$

Karşılaştırmalı Dinler Tarihi alanında yazılan kitapların sayısının arttığı bir dönemde Bouquet "Comparative Religion, 1942" (Karşlaştırmalı Din) çalışmasıyla İngiltere'de Kellet'in izinde dünya dinleri paradigmasının yayılmasına hizmet etmiştir. İngiliz Kilisesi papazlarından olan Bouquet, Cambridge Üniversitesinde Karşılaştırmalı Dinler Araştırması kürsüsüne atandığı bir dönemde kaleme aldığı bu eserin önsözünde, Hıristiyanlığa mutlak anlamda inanmasına rağmen bu durumun diğer dinler hakkında önyargısız ve tarafsız bilgiler vermesine engel olmadığını ortaya koyar. Bu doğrultuda kitabını bilimsel açıdan kaleme alacağını, dolayısıyla yargıç olarak değil bilim adamı olarak hareket edeceğini belirterek, kitap hakkında son değerlendirmeyi okuyucuya bırakır. ${ }^{69}$

Eserinin başında din kavramını irdeleyen Bouquet, bu kavramın

${ }^{66}$ Ernest Edward Kellet, A Short History of Religions (London: Victor Gollancz Ltd., 1933), Prefatory Note; Cox, From Primitive to Indigenous, 36.

67 Kellet, $A$ Short History of Religions, 576.

68 Cox, From Primitive to Indigenous, 36.

${ }^{69}$ Alan Coates Bouquet, Comparative Religion: A Short Outline (London: Penguin Books, 1953), V. 
Avrupa'ya özgü olduğunu ve dünya ölçeğinde belli insan ilgilerini kapsayan bir terim olarak Avrupalı bir uzlaşım niteliği taşıdığını ifade eder. ${ }^{70}$ Dinleri tasnif etmenin kaçınılmaz bir durum olsa da kendi başlarına dinleri anlamada yeterli olmadığını düşünen Bouquet, yine de "halen yaşayan ve genişleyen dinler (İslam vb.)", "yaşayan ancak değişmeyen/durağan dinler (Yahudilik vb.)" ve "yaşamayan dinler (Maniheizm vb.)" olmak üzere dinler arasında doğal bir ayrımın yapılabileceğine işaret eder. ${ }^{71}$ Ayrıca "Din nasıl başladı?" sorusuna cevap arayan Bouquet, benlik ve ego gibi psikolojik kavramlar çerçevesinde bir açıklamaya başvurur. ${ }^{72}$

Mezopotomya, Mısır, Yunan ve Roma gibi bölgelerde tezahür eden antik dinlere kısaca temas eden Bouquet, özellikle tanrı anlayışları bağlamında bu dinler arasında bir karşılaştırma yapmak suretiyle, güneş tanrısından yüce tanrıya kademeli bir geçişin söz konusu olduğunu bir tablo yardımıyla ortaya koyar. ${ }^{73}$ Ardından Hindistan Fenomeni başlığında Hinduizm, Budizm, Caynizm ve Sihizm başta olmak üzere bu coğrafyada yaşayan dinleri; Çin ve Japonya başlığında bu coğrafyada hâkim olan Konfüçyanizm, Taoizm ve Şintoizm gibi dini gelenekleri ve sonrasında Yahudilik, Hıristiyanlık ve İslam dinlerini incelemiştir. ${ }^{74}$ Yaptığı incelemelere göre Bouquet'in karşılaştırmalı yöntemi tarihsel tasvir olup bunu kitabın başından sonuna kadar bütün dinlere uygulamıştır. ${ }^{75}$ Ancak her ne kadar coğrafi tasnifleri kullanmaya gayret gösterse de dünya dinleri paradigması dairesinden uzaklaşamamıștır. ${ }^{76}$

Sonuç kısmında Bouquet, Söderblom'un dinler tasnifi listesinin kullanılabilirliğine işaret ederek, kendisinin din yorumuyla aynı noktada durduğunu dile getirdiği Gerardus Van der Leeuw'ün Religion in Essence and Manifestation (1938) adlı eserinde yer alan şu sözlerinin en iyi sonuç cümleleri olacağını belirtmektedir: "Hiçbir dini tecrübe, sadece bir eğilim değildir. Aksine durum içindeki aktif fail insanın kendisi değil ancak Tanrı'dır. İlahi irade, günümüzün büyük ölçüde sekülerleşmiş medeniyeti tarafindan maskelenmiş dini hareketlerin yanı sıra Hıristiyanlıktaki ilkelinden gelişmişine varıncaya kadar bütün fenomenlere aynı şekilde güç vermektedir".77 Buna

\footnotetext{
70 Bouquet, Comparative Religion, 13-19.

71 Bouquet, Comparative Religion, 25-26.

72 Bouquet, Comparative Religion, 38-39.

73 Bouquet, Comparative Religion, 94-95.

74 Bouquet, Comparative Religion, 116-285.

75 Mustafa Ünal, Din Fenomenolojisi: Tarihçe, Yöntem ve Uygulama (Kayseri: Geçit Yayınları, 1999), 24

76 Cox, From Primitive to Indigenous, 37.

77 Bouquet, Comparative Religion, 302.
} 
göre Bouquet, Söderblom'un listesine eklemeyi teklif ettiği Hıristiyan temelli "devam eden vahiy/tezahür" kategorisini desteklemek istemektedir. ${ }^{78}$

Bouquet'in dünya dinleri paradigmasını benimseyen bu kitabı ve karşılaştırmalı yaklaşımı, batılı birçok bilim adamı tarafından benimsenmiş olup bazısına daha önce temas edildiği üzere benzer nitelikte pek çok kitap yazılmıştır. Bunlardan bazıları din bilimcileri Edward J. Jurji'nin, The Great Religions of the Modern World (1947), Huston Smith'in The Religions of Man (1958), Geoffrey Parrinder'in The WorId's Living Religions (1964), John B. Noss'un Man's Religions (1966), Ninian Smart'in The Religious Experience of Mankind (1969) ve John Alexander Hutchison'un Paths of Faith (1969) adlı çalışmalarıdır. ${ }^{79}$

Buraya kadar verilen bilgilere göre Amerika ve İngiltere'de belli başlı dinler ekseninde kaleme alınan, dolayısıyla dünya dinleri paradigması etrafında şekillendikleri ifade edilen çalışmaların hem akademide hem de eğitim de etkili olduğu ve kitleleri yönlendirdiği görülmektedir. Bu durum sadece bu iki ülke ile sınırl değildir. Örneğin Almanya'da da Carl Clemen "Religions of the World: Their Nature and their History, 1931" (Dünya Dinleri: Doğaları ve Tarihleri) adlı eseriyle bu anlayışın öncüsü kabul edilmektedir. 80 Türkiye'de Dinler Tarihi alanında yapılan çalıșmalara bakıldığında dünya dinleri paradigmasını yansıtan çalışmaların ${ }^{81}$ yanında esas olarak Yahudilik, Hıristiyanlık ve İslam etrafında şekillenen çalışmaların hâkim olduğunu görmek ve tabiri caizse "ilahi dinler paradigması" olarak değerlendirmek mümkündür. ${ }^{82}$

\footnotetext{
78 Bouquet, Comparative Religion, 294-295.

79 Ünal, Din Fenomenolojisi, 24.

80 Cox, From Primitive to Indigenous, 37-38.

81 Bu bağlamda Diyanet İșleri Bașkanlığı'nın koordinatörlügünde ve Şinasi Gündüz'ün editörlüğünde yayınlanan Yașayan Dünya Dinleri (2007) adlı çalıșma önemli bir örnektir. Dinler tarihçisi akademisyenlerin katkılarıyla hazırlanan çalışmada İslam, Hıristiyanlık, Yahudilik, Hinduizm, Budizm, Caynizm, Sih Dini, Konfüçyanizm, Taoizm, Sabilik, Maniheizm, Mecusilik, Eski Türk Dini, İslam Öncesi Arap Dini, Batıda Ortaya Çıkan Yeni Dinî Akımlar ile İslam Dünyasında Ortaya Çıkan Senkretik Akımlar ele alınmıştır. Herhangi bir normatif veya ideolojik kaygı taşımadan Dinler Tarihini halka indirebilmeyi başaran çalışma Dinler Tarihi alanını popülerleştirip aktüelleştirdiği için takdir edilmiştir. Bk. Mustafa Alıcı, "Dinler Tarihini Popülerleștirmek: Yașayan Dünya Dinleri Adlı Çalıșma Üzerine Bir Kaç Söz", Milel ve Nihal: İnanç, Kültür ve Mitoloji Araştırmaları Dergisi 4/2 (2007): 163- 171.

82 Örneğin özellikle Hikmet Tanyu'nun doğrudan ya da dolaylı olarak yetiștirdiği kușak içinde, fenomenolojik metotla yazıldığı kabul edilen Mehmet Aydın'ın "illahi Dinlerde Șeytan", Osman Cilacı'nın "Psiko-Sosyal Açıdan İlahi Dinlerde Dualar" ve "İlahi Dinlerde Cennet Inancı: Mukayeseli Bir Araștırma", "İlahi Dinlerde Oruç, Hac ve Kurban", Günay Tümer'in "Hıristiyan ve Íslam Dinlerinde Meryem", Ali Erbaş’ın "Melekler Âlemi: Illahi
} 


\section{Modern Dönemde Morfolojik Dinler Tasnifi Yaklaşımına Yönelik Eleştiriler}

Özellikle 1960'lı yıllardan itibaren başta Amerika ve İngiltere'de akademi ve eğitim dünyasında, dünya dinleri kavramının yaygın olarak kullanılması nedeniyle morfolojik karakterdeki dinler tasnifine yönelik eleştiriler de yine bu bağlamda yapılmıştır. Bu süreçte özellikle alanlarında etkili olan Wilfred Cantwell Smith (1916- 2000) ve Ninian Smart (19272001), görüşleriyle dünya dinleri paradigmasını temsil eden çalışmalara benzer açllardan meydan okuyan ilk din bilimcileri olmuşlardır.

Smith ve Smart, Batı dini araştırmalar literatüründe din kavramının statik bir kavram olarak kullanıldığını vurgulayıp araştırmaların belli başlı dinler etrafında dinlerin değişmeyen özlere sahip olduğu anlayışından hareketle kurgulanmasına karşı çıkmışlardır. Bu itibarla Smith, din yerine "iman" ve dinler yerine "kümülatif/birikimsel gelenek" tabirlerini kullanmayı teklif ederken;83 Smart, din yerine "dünya görüşü" kavramını kullanmayı teklif edip dinin, yaşayan bir organizma olduğunu belirterek bütün boyutlarıyla araştırma konusu edilmesi gerektiğini savunmuştur. ${ }^{84}$ Ancak Smart eserlerinde özellikle coğrafi yaklaşımı esas almak suretiyle dünya dinleri paradigmasına göre bir kategorizasyon benimsemekle birlikte, dinleri boyutsal açıdan incelemek ve Marksizm ve Ulusalcıllk gibi seküler hareketleri de araştırmalarına dâhil ederek bu algıdan kurtulmaya çalışmıştır. ${ }^{85}$ Cox'a göre dini araştırmalara yeni bir temel arayan Smith ve Smart'ın görüşleri dünya dinleri paradigmasını aşmada yetersiz kalmıştır. Çünkü onlar dinler nasıl incelenmeli, öğretilmeli ve akademik çevrelerde ve geniş kitlelerde nasıl yorumlanmalı konularına odaklanmışlardır. Buna rağmen dinlerin tarihi ve metinsel değil inanan merkezli anlaşılmasıyla ilgili çabaları nedeniyle konuya yönelik farkındalık seviyesini artırmışlardır. 86

\footnotetext{
Dinlerde Melek Inancı", Galip Atasagun'un "İlahi Dinlerde Dini Semboller”, Sami Kılıç'ın "İlahi Dinlerde Yiyecekler ve İçecekler" ve Mehmet Katar'ın "İlahi Dinlerde Tövbe Anlayışı Üzerine Bir Araştırma" gibi çalıșmaları bu bağlamda değerlendirilebilir. Bk. Emir Kuşcu, “Türkiye'de Din Fenomenolojisiyle İlgili Yayınlar Üzerine Bir Değerlendirme”, İ. Ü. İlahiyat Fakültesi Dergisi 2/1 (2011): 132. Bu tarz çalışmalar Türkiye'de Dinler Tarihine yönelik ilgiyi ve farkındalığı artırmış ve kendilerinden sonra yapılan çalışmalar için örnek teşkil etmiştir.

83 Wilfred Cantwell Smith, The Meaning and End of Religion (New York: Mentor Books, 1964), 141.

${ }^{84}$ Ninian Smart, The Religious Experience of Mankind (New York: Charles Scribner's Sons, 1969), 31.

85 Örnek olarak bk. Ninian Smart, Dimensions of the Sacred: An Anatomy of the World's Beliefs, Berkeley (London: Harper Collins, University of California Press, 1996).

86 Cox, From Primitive to Indigenous, 44.
} 
Ayrıca din kavramı eleştirileriyle kendilerinden sonraki din bilimcilerinin çalışmaları için önemli referanslar olmuşlar ancak dinlerin “-ism" (-izm) ekiyle dünya dinleri olarak tanımlanmalarını ve bu şekilde kullanılmalarını engelleyememişlerdir. ${ }^{87}$

Smith ve Smart'ın eleştirilerini takiben dünya dinleri paradigmasına yönelik ciddi eleştiriler yönelten ve günümüz dini araştırmalarında önemli çalışmalara imza atan Jonathan Z. Smith, Tomoko Masuzawa ve James L. Cox, hem bu paradigmanın ne'liğini netleștirmekte hem de nasıl ve neden aşılması gerektiğine dair önemli görüşler ortaya koymaktadır.

Amerikalı dinler tarihçisi Jonathan Z. Smith (1938-2017), büyük ölçüde Eliade'ın kullandığı kavramları eleștirdiği “Map is Not Territory, 1978” (Harita Toprak Değildir) adlı çalışmasıyla dünya dinleri paradigmasına anahtar eleștiriler yöneltmiştir. Öncelikle ona göre, Batı dünyasındaki akademik disiplinlerin kökeninde antik Yunandaki "biz" ve "onlar", başka bir ifadeyle "Yunan" ve "Barbar" şeklindeki ayrım yer almış ve ortaya çıkan "öteki" anlayışı XIX. ve XX. Yüzyılın emperyalist ve kolonyalist entelektüel yaklaşımlarını şekillendirmiştir. Bu anlayışı benimseyen ve kahir ekseriyeti oluşturan batılı akademisyenlere göre dünya, "insan denilen tarih yapanlar" ve "insan dışı denilen tarihe maruz kalanlar" olmak üzere iki kategoriye ayrılmış durumdadır. Bu itibarla Batı aktif, tarih yapan ve insan iken; Doğu statik, tarihe maruz kalan ve insan olmayandır. Bu doğrultuda batılı din araştırmalarında bir din, batılı din anlayışına benzediği/uyum sağladığı ölçüde bir dünya dini olarak nitelendirilmiștir. Bu durum, ilkel dinlerin ikincil pozisyonda yer almasına yol açmakta ve bu dinler pek çok Afrika kilisesi ve Batı'da ortaya çıkan yeni dini hareketlerde olduğu gibi kendilerini dünya dinlerine uyarladıkları ölçüde değer kazanmaktadır. İlkel dinler bir dünya dini olduklarını kanıtlamak için bir dini dünya dini şeklinde nitelendirmeye yol açacak özellikleri gösterdiklerinde dünyanın jeopolitik aşamasına geçebilmektedirler. Çünkü dünya dinleri kategorisi, dinleri jeopolitik fenomenler haline dönüștürmüș durumdadır. Dolayısıyla o, Smith ve Smart ile benzer noktada durmakla birlikte, dinin doğası hakkında yapılan yeni değerlendirmelerin başarısızlığını, teklif edilen haritacıllı̆ın süregelen haritanın bir görüntüsünü devam ettirdiği düşüncesiyle itiraf etmektedir. ${ }^{88}$

J. Z. Smith'in dinlerin, Batı tarafından belirlenmiş kriterler - özellikle

87 Cox, "Before the 'After' in 'After World Religions'- Wilfred Cantwell Smith on the meaning and end of religion", After World Religions: Reconstructing Religious Studies, ed. Christopher R. Cotter, David G. Robertson (London, New York: Routledge, 2016), XVI. 88 J. Z. Smith, Map is Not Territory, 294-296; Cox, From Primitive to Indigenous, 45. 
Hıristiyanlık örneklemi- çerçevesinde din/dinler olarak tasnif edildiği düşüncesi, Tomoko Masuzawa'nın görüşlerinin temelini oluşturmaktadır. Zira Masuzawa'nın, "The Invention of World Religions: Or, How European Universalism Was Preserved in the Language of Pluralism, 2005" (Dünya Dinlerinin İcadı: Veya Avrupa Evrenselciliğinin Çoğulculuk Dilinde Nasıl Korunduğu) adlı kitabı Hıristiyan teolojisinin evrenselliğinin ve Avrupalı dünya görüşünün dünya dinleri paradigmasıyla yayılmaya ve sürdürülmeye çalışıldığı varsayımına dayanmaktadır. ${ }^{89}$

Masuzawa, dünya dinleri paradigmasını, XIX. Yüzyıldan itibaren diğer dinleri Hıristiyanlıktan ayırmak için dinlerin Doğu-Batı olarak ikili ve doğdukları coğrafyaya istinaden Yakın Doğu (Yahudilik, Hıristiyanlık, İslam), Güney Asya (Hinduizm, Budizm, Zerdüştilik, Caynizm, Sihizm) ve Uzak Doğu (Konfüçyanizm, Taoizm, Şintoizm) olarak üçlü tarzda tasnif edilip kullanılagelmesi şeklinde tanımlamaktadır. ${ }^{90} \mathrm{Bu}$ bağlamda özellikle I. ve II. Dünya savaşı dönemlerinde din bilimcilerin yaşanan küresel krizler karşısında barışın teminine katkı sağlayıcı bir zemin sunmak amacıyla tarihi dinlerden ziyade yaşayan dinlere odaklandıklarını belirtmektedir. Örnek olarak din bilimcileri Robert Ernest Hume'un The World's Living Religions (1924), Alban G. Widgery'in Living Religions and Modern Thought (1936), William Ernest Hocking'in Living Religions and a World Faith (1940) ve R. C. Zaehner'in editörlüğünde The Concise Encyclopedia of Living Faiths (1956) adlı kitaplarından bahseder. ${ }^{91} \mathrm{Bu}$ anlayışın batılı din bilimcilerinin dinleri küresel önemleri açısından incelemeye ve yorumlamaya teşvik ettiğini ileri sürmekle J. Z. Smith ile aynı görüşü paylaşan Masuzawa, bunun sonucunda ilkel dinlere yönelik ilginin giderek azaldığını ve dönemin popüler Dinler Tarihi çalışmalarında bunun görülebileceğini ifade etmektedir.92 Ancak modern dönemde söz konusu durumdan rahatsız olan din bilimcilerinin varlığına dikkat çekip Ninian Smart'ın "The Religious Experience of Mankind, 1969" (İnsanoğlunun Dini Tecrübesi) adlı eserinde yaşanan dönüşümlere işaret etmektedir. Nitekim bu kitapta, 1969 tarihli ilk baskısından The Religious Experience adı ile 1996'daki son baskısına kadar hem ilkel dinlere dair kapsamın genişlemesi hem de konu başlıklarının revize edilmesiyle ilgili değişiklikler vardır. ${ }^{93}$

${ }^{89} \mathrm{Bk}$. Richard King, "Taking on the guild: Tomoko Masuzawa and The invention of world religions", Method and Theory in the Study of Religion 20/2 (2008): 125-133.

${ }^{90}$ Masuzawa, The Invention of World Religions, 2-3.

91 Masuzawa, The Invention of World Religions, 40.

92 Masuzawa, The Invention of World Religions, 3-4; Cox, From Primitive to Indigenous, 46.

93 Masuzawa, The Invention of World Religions, 5. 
Masuzawa'nın dünya dinleri paradigmasına itirazının diğer yönünü, bu anlayışta bütün dinlerin evrensel bir öze sahipmiş gibi görülüp değerlendirilmesidir. ${ }^{94} \mathrm{Bu}$ tarz kitapların giderek yaygınlaşmasını, hatırı sayılır satış rakamlarına ulaşmasını ve eğitim materyali olarak kullanılmasını olumsuz karşılayan Masuzawa,95 bu çalışmaların, XIX. Yüzyılda Hıristiyanlığın diğer dinlerden üstünlügünü ispat etmek amacıyla karşılaştırmalı ve Hıristiyan varsayımlarıyla yüklü olarak kaleme alınan James Clement Moffat'ın A Comparative of History of Religions (1871-1873) ve Samuel Henry Kellog'un A Handbook of Comparative Religion (1899) tarzındaki çalışmalarla amaç ve söylem bakımından benzer olduğunu düşünmektedir. Çünkü dünya dinleri paradigmasını yansıtan çalışmalardaki evrensel özün Hıristiyan kavramlar ve doktrinler etrafında şekillendiğini ifade etmek suretiyle bu çalışmaların Hıristiyan merkezli gizli teolojik gündem taşıdıklarını ima etmektedir. ${ }^{96}$

"From Primitive to Indigenous: The Academic Study of Indigenous Religions, 2007" (Illkelden Yerliye: Yerli Dinlerin Akademik İncelemesi" adlı kitabının "Essentialism and the World Religions Paradigm" (Özselcilik ve Dünya Dinleri Paradigması) bölümünde dünya dinleri paradigmasının teşekkül sürecini ve mevcut durumunu analiz eden James L. Cox, Batı'da XX. Yüzyılda hem lisans eğitiminde kullanılan kitaplarda hem de popüler çalışmalarda paradigmanın gömülü olduğunu ifade ettikten sonra ortaya konan -dünya dinleri kategorisinin Hıristiyanlı̆̆ı öncelediği ve bütün dinlerin aynı öze sahip olduğu- varsayımlar çerçevesinde, çeşitli popüler çalışmalar üzerinden konuyu değerlendirmektedir. Bu amaçla paradigmanın aşılması noktasında gayret gösterdiklerini ifade ettiği Lancaster Üniversitesi Dini Araștırmalar bölümü profesörlerinden Linda Woodhead (1964-)'in editörü olduğu Religions in the Modern World (2002) adlı kitapla ilgili değerlendirmeleri anlayışının temel parametrelerini sunmaktadır.

Üniversite eğitiminde kullanılmak üzere 2002 tarihinde ilk baskısı yayımlanan "Religions in the Modern World: Traditions and Transformations" (Modern Dünyada Dinler: Gelenekler ve Dönüşümler) adlı bu kitap, 2016 yılında çeşitli eklemeler ile üçüncü baskısına ulaşmıştır. Smart'ın kurucusu olduğu Lancaster Üniversitesi Dini Araştırmalar bölümü akademisyenlerinin katkılarıla, Smart'in "The World's Religions: Old Traditions and Modern Transformations, 1989” (Dünya Dinleri: Gelenekler ve Modern Dönüşümler)

${ }_{94}$ Cox, From Primitive to Indigenous, 46.

95 Masuzawa, The Invention of World Religions, 9.

${ }_{96}$ Masuzawa, The Invention of World Religions, 103-104. 
adlı kitabı model alınarak şekillenen bu kitapta Smart'ın küresel ve disiplinler arası yaklaşımının etkisi büyüktür. ${ }^{97}$ Kitabın ilk baskısını esas alan ve iki kısımda değerlendiren Cox, ilk kısımda Smart ile benzer şekilde dini geleneklerin (Hinduizm, Budizm, Sihizm, Çin Dinleri, Japon Dinleri, Yahudilik, Hıristiyanlık, İslam, Afrika Dinleri, Amerika Yerli Dinleri, Yeni Dini Hareketler) büyük ölçüde geleneksel yaklaşımlarla incelendiğine, ikinci kısımda ise sekülerlik, küreselleşme, cinsiyet, siyaset ve maneviyat gibi çağdaş konuların din ile etkileşiminin ele alındığına dikkat çekmektedir. Genel anlamda ilk kısımda dinin müstakil bir yapı olarak kabul edildiği ve kendi kavramları aracılığıyla incelendiği bir yaklaşımın hâkimken, ikinci kısımda toplumsal değişimlerle beraber dinde gerçekleşen değişimlere odaklanılması nedeniyle sosyolojik, antropolojik ve etnografik bakış açılarına da yer verildiğini ifade etmektedir. İçerik açısından birinci kısmın on iki ve ikinci kısmın beş bölümden oluştuğunu belirten Cox, genel itibarıyla kitapta geleneksel yaklaşımın hâkim olduğunu belirtmektedir. ${ }^{98}$

Bu kitapla ilgili olarak İngiliz din bilimcisi Irwing Hexam (1943)'ın “nihayet 1960’lardaki kitapların klonu olmayan bir dini araştırmalara giriş kitabı" nitelemesini değerlendiren Cox, yazarların dinleri dinamik ve sosyal şartlarla bağlantılı olarak ele almalarını takdir etmekte ancak dinlerin müstakil, homojen bütünler şeklinde sunulduğu ve önceki metinlerde vurgulanan temel kategorilere itiraz edilmediği gerekçesiyle Hexam'ın görüşüne tam olarak katılmamaktadır. Afrika ve Amerika dinleri ile yeni dini hareketlerin çalışmada yer almasının dünya dinleri paradigmasını aşmaya hizmet ettiğinin düşünebileceğini belirten Cox, ancak bu dinlerin içerikte yer almasının yeni bir durum olmadığını çünkü İngiliz dinler tarihçisi Edward Geoffrey Parrinder'ın “The World's Living Religions, 1964" (Yaşayan Dünya Dinleri) adlı eserinde bu dinleri araştırmaya dâhil ettiğini vurgulamaktadır. Diğer taraftan yeni dini hareketlerin büyük dini gelenekler gibi müstakil yapılar şeklinde değerlendirip incelenmesinin dünya dinleri paradigmasını pekiştirmeye hizmet ettiğini belirten Cox'a göre Woodhead'in editörü olduğu kitap söz konusu edilen paradigmayı önceleyen bir yapıya sahiptir. ${ }^{99}$

Ancak bu kitabın 2016 yılında yayımlanan son baskısı, yapılan eleştiri

97 Bk. Linda Woodhead v. dğr. (Eds.), Religions in the Modern World: Traditions and Transformations (London: Routledge, 2002); Teemu Taira, “Doing Things with 'Religion': A Discursive Approach a Rethinking the World Religions Paradigm", After World Religions: Reconstructing Religious Studies, ed. Christopher R. Cotter, David G. Robertson (London, New York: Routledge, 2016), 76.

98 Cox, From Primitive to Indigenous, 48-49.

${ }^{99}$ Cox, From Primitive to Indigenous, 49. 
ve uyarılar gözetilmek suretiyle -her ne kadar çeşitli kategoriler devam ettirilse de- ilk baskısından oldukça farklı bir yapıya bürünmüştür. Öyle ki, yeni olarak Sihizm, İslam, Afrika'da Din, Modern Ezoterizm, Din ve Göç, Din ve Siyaset, Din ve Şiddet gibi konular bazısı güncellenerek bazısı da ilk defa ele alınarak uzmanlar tarafından konu edilmiştir. Genel olarak din mensuplarına inançlarının onlar için ne ifade ettiğine, günlük yaşamlarını ne şekilde etkilediğine ve dinin pratiklerini nasıl icra ettiklerine dair ifadelere bölümler içerisinde özellikle yer verilerek, içerden ve dışarıdan bakanların dini/dinlerini ne şekilde anladıkları veya tatbik ettikleri bir bütün olarak ortaya konmaya gayret edilmiştir. Ayrıca katkı sağlayan din bilimcilerin kendi alanları ve yöntemlerine göre konuları ele almaları, çalışmanın çok metotlu ve disiplinler arası olarak şekillenmesini sağlamıştır. Dolayısıyla kitap Cox'un eleştirdiği çalışma olmaktan uzaklaşmış görünmektedir. ${ }^{100}$

Bu kitapla beraber İngiliz dinler tarihçisi John Hinnell (1941-2018)'in "New Handbook of Living Religions, 1997" (Yaşayan Dinlerin Yeni El Kitabı) adlı eserini de hemen hemen aynı açlardan eleştiren Cox, ${ }^{101}$ seçtiği bu örneklerden hareketle XXI. Yüzyıl dini araştırmalarında dünya dinleri paradigması olarak nitelendirdiği anlayışın hâkim olduğu sonucuna varmaktadır. Woodhead ve Hinnell gibi din bilimcilerini yalnızca dinlerin sosyal konularla etkileşimini odaklanıp dünya dinleri paradigmasının yetersizliklerinden kurtulmaya çalışmakla itham etmektedir. Dolayısıyla ona göre bu yüzyılda popüler olan dini çalışmalar kendilerinden önce yapılan çalışmaların seviyesini geçmekle birlikte dinleri belli kategoriler altında incelemede ve bu kategorilerin altında yatan politik ve teolojik varsayımları devam ettirmede aynı noktada durmaktadırlar. ${ }^{102}$

J. Z. Smith ile Masuzawa'nın konuya dair çözüm önerilerinin muğlaklığına karşılık Cox’a göre dünya dinleri paradigmasını aşmanın yolu dini yeniden değerlendirmekten ve bu paradigma yerine yeni bir model geliştirmekten geçmektedir. ${ }^{103} \mathrm{Bu}$ doğrultuda kitabının "Towards a Sociocultural, Nonessentialist Interpretation of Religion" (Sosyokültürel, Özselci Olmayan Bir Din Yorumuna Doğru) bölümünde bu modelin ne şekilde olabileceğini tartışmaktadır. Önemli ölçüde din bilimcisi Timothy Fitzgerald (1947-)'ın dinleri, sosyokültürel yapıları bağlamında inceleme teklifinden ve Fransız sosyolog Daniele Hervieu-Leger (1947-...)'in dinleri, tanrı veya diğer

100 Bk. Linda Woodhead v. dğr. (Eds.), Religions in the Modern World: Traditions and Transformations (London: Routledge, 2016).

101 Cox, From Primitive to Indigenous, 49-50.

102 Cox, From Primitive to Indigenous, 51.

103 Cox, From Primitive to Indigenous, 52. 
özlerden ziyade bir gelenek zinciri olarak görmesinden etkilenen Cox, dinleri sosyokültürel bağlamlarına atıfta bulunacak şekilde otoriter bir gelenek zinciri olarak kabul etmenin, onları incelemek için teolojik varsayımlara ve özlere dayanmayan ancak post modern bakış açılarına yer veren bir model sunduğunu ifade edip dünya dinleri paradigmasını aşmak için kullanmayı teklif etmektedir. ${ }^{104}$ Ancak onun bu yaklaşımının araştırma konusu ettiği yerli dinleri, ${ }^{105}$ dünya dinleri kategorisinde yer alan dünya dinleri seviyesine taşımaktan öte bir anlama sahip olmadığı da belirtilmektedir. ${ }^{106}$

Genel olarak morfolojik yaklaşım bağlamında dünya dinleri paradigmasına yönelik eleştirilere bakıldığında dinlerle ilgili ortaya konan kategorilerin teolojik ve politik varsayımlara dayandığı ve işaret edilen özlerin Hıristiyanlık veya büyük dinlerin tahakkümüne hizmet ettiği genel kanaat olarak kabul edilmektedir. Cox örneğinde görüldüğü üzere dünya dinleri paradigmasının aşılmasıyla ilgili olarak ise din kavramının yeniden değerlendirilmesi gerektiği ve dinlerin bağlamlarından, inananlarından, sosyokültürel ve küresel temalardan soyutlanarak anlaşılamayacağı gibi çeşitli anlayışlar ortaya çıkmaktadır. Bu durum, dinleri belli kategoriler etrafında ele almaktan daha öte, dini bütün yönlerini kapsayan, inanan odaklı, disiplinler arası ve sosyokültürel ve küresel konulara duyarlı dini araştırmalar ihtiyacını vurgulamaktadır.

$\mathrm{Bu}$ açıdan bir örnek olması bakımından İngiliz din bilimcisi Kim Knott (1955)'un, Woodhead'in editörlügündeki Religions in the Modern World (2016) kitabında yer alan "How to Study Religion" (Din Nasıl İncelenir) bölümünde konuya dair değerlendirmeleri dikkat çekicidir. Dini, tarihi ve sosyal bir fenomen olarak gören Knott, modern dünyada dini araştırmaların, son iki yüzyılda dünyada etkili olan kolonyalizm, post-kolonyalizm, küreselleşme ve küresel dini hareketlerin ortaya çıkışı gibi çeşitli süreçler ve konularla etkileşimdeki yöntemleri, yaklaşımları ve teorileri gerektirdiğini ifade etmektedir. $\mathrm{Bu}$ nedenle dini araştırmalarda tarihi, sosyolojik, antropolojik, teolojik ve psikolojik gibi birçok yöntemin kullanımına devam etmekle birlikte, ortaya çıkan çağdaş problemler ve konuların çok metotlu, disiplinler arası araştırmalar bağlamında incelenmesini teklif etmektedir. Çünkü erken dönem dini araştırmalar kutsal metinler ve inançlar merkezli

104 Bk. Cox, From Primitive to Indigenous, 75-95.

105 Bu bağlamda Cox, Restoring the Chain of Memory T.G.H. Strehlow and the Repatriation of Australian Indigenous Knowledge (2018) ve The Invention of God in Indigenous Societies (2014) tarzında çalışmalar kaleme almıştır.

106 Suzanne Owen, "The World Religions paradigm Time for a Change", Arts \& Humanities in Higher Education 10/3 (2011): 256. 
olmasından ötürü geleneksel olarak çeşitli metinsel yöntemlerle ilişkili iken, modern dönemdeki durum anket, röportaj ve katılımcı gözlem gibi sosyal araștırma metotlarını yaygın olarak kullanmayı da gerektirmektedir. Hatta araştırma konusuyla ilişkili olarak fotoğraf ve video gibi görsel medya, katılımcı ve diyalojik yöntemler de din bilimcilerinin deyim yerindeyse alet çantası içerisinde bulunmalıdır. Ayrıca Knott, dünya dinleri paradigmasında yerel dinlerin dışlandığı kanaatine karşı, yerel ve küresel dinlerin/inançların birbiriyle bağlantılı olmalarından ötürü dinleri/dindarları anlamada bu ilişkinin göz ardı edilemeyeceğini belirtmektedir. Sonuç olarak, dinin incelendiği yöntemin araştırmacının bakış açısı veya geçmiş deneyiminden etkilendiğini düşünen Knott, kendi dinlerimiz kadar başkalarının dinlerini araştırırken ahlak, cinsiyet ve güç konularının bilincinde hareket etmenin oldukça önemli olduğunu vurgulamaktadır. Bu şekilde dini araştırmalarda araştırma konularının ve yöntemlerinin güncellenerek kapsamlarının genişletilmesi- pek çok din bilimcisinin de mutabık olduğu- anlayışı için bir örnek teşkil etmekte, dolayısıyla Cox ile aynı amaç ancak farklı yaklaşım doğrultusunda hareket etmektedir. ${ }^{107}$

\section{Sonuç}

Genel anlamda ötekini/diğerini dini inançları üzerinden bilme, tanıma, anlama ve anlamlandırma amacı taşıyan bir disiplin olarak temayüz eden Dinler Tarihi, başlangıcından günümüze bu amaca tam anlamıyla ulaşmak için çeşitli yöntemleri ve yaklaşımları ihtiva etmiştir. Zira dinler hakkında malzemelerin artarak çoğalması, zamansal ve mekânsal unsurlarda meydana gelen değişimler bu durumu gerekli kılmıştır. Bu çerçevede ortaya çıkan dinler tasnifi yöntemi, dinlerin kendi anlayışları etrafında şekillenen hakbatıl tarzındaki tasniflerini kimi zaman hareket noktası kabul ederek kimi zaman da eleştiri konusu yaparak gelişmiştir. Bu bağlamda çeşitli dinler tasnifi yöntemleri gelişmekle beraber, dinleri biçimsel özelliklerine göre tasnif eden morfolojik dinler tasnifi, bu yöntemi sistematize etmesi ve dinamik hale getirmesi bakımından ön plana çıkmıștır.

Özellikle XIX. Yüzyılın ikinci yarısında hâkim olan ve XX. Yüzyılın ortalarına kadar Batı'daki dini araştırmalarda kullanılan dinin kaynağına ilişkin görüşleri morfolojik dinler tasnifinin ilk tezahürleri olarak değerlendirmek mümkündür. Çünkü bu teorilerde dinler, politeist tanrı anlayışından monoteist tanrı anlayışına ulaşan kategorik bir ölçeğe göre 
değerlendirilmişlerdir. Evrimci teorilerin hareketlendirdiği bu tartışma ortamında Max Müller'in dil teorisi bağlamında dinleri tasnif etmesi yapılan çalışmalara akademik bir ivme kazandırırken esas olarak morfolojik dinler tasnifini sistematize eden din bilimcisi olma payesini Cornelius Petrus Tiele kazanmıştır.

Tiele'nin özellikle dinleri ahlaki dinler olarak kategorize etmesi ve kategori altında evrensel/dünya dinleri kategorisine yer vermesi morfolojik dinler tasnifi açısından bir dönüm noktası olmuş ve onu takiben ortaya çıkan dinler tasniflerini de önemli ölçüde etkilemiştir. Asıl olarak Tiele'nin önemi, kıta Avrupa'sında bilinmesine ve üzerine tartışmalar yapılmasına rağmen İngilizce konuşulan yerlerde bilinmeyen "dünya dinleri" kavramını bu çevrelere tanıtmış olmasından gelmektedir. Nitekim bu süreç Amerika ve İngiltere başta olmak üzere Dinler Tarihi çalışmalarının yoğunlaştığ 1 yerlerde akademik ve popüler çalışmaların, Hıristiyanlık, Budizm, İslam, Hinduizm ve Yahudilik dinlerinin daimî üye olduğu; Konfüçyanizm, Taoizm, Şintoizm, Caynizm, Sihizm ve Zerdüştilik dinlerinin ise sıklıkla kullanıldığı bir dinler listesi ekseninde şekillenmesine kadar uzanmıştır.

Buna karşılık Wilfred Cantwell Smith ve Ninian Smart gibi öncü din bilimcileri, dini araştırmaların öteki dinleri ikinci planda değerlendiren Batı merkezliliğine işaret edip, özellikle dinin yeniden tanımlanmasına yönelik önemli teşebbüslere girişmek suretiyle halefleri için önemli bir bilimsel zemin sunmuşlar ve konuya yönelik farkındalık oluşturmuşlardır. Bu doğrultuda Jonathan Z. Smith'in Batı Dinler Tarihi literatürünün Batı-Doğu ikilemine göre şekillendiği görüşü, Tomoko Masuzawa'nın The Invention of World Religions (2005) "Dünya Dinlerinin İcadı" adlı çalışmasına ilham kaynağı olmuş ve iki din bilimcisinin görüşleri James L. Cox’un dini araştırmalarda batılı dinler kategorilerinin ve kavramlarının kullanılmasını ve hâkimiyetini "dünya dinleri paradigması" şeklinde nitelendirmesini sağlamıştır. Onların görüşleri ekseninde incelenen Dinler Tarihi çalışmaları örneklerinden hareketle, bu çalışmalarda altında hangi dinler tasnifi yer alırsa alsın morfolojik karakterdeki dünya dinleri kategorisinin üst bir kategori olarak kullanılmakta olduğunu ve belli başlı dinleri kapsayan bir dinler listesi sunduğunu görmek ve bu durumun alandaki pek çok çalışmayı kapsadığını söylemek mümkündür.

Dünya dinleri paradigmasına yönelik eleştiriler, kategorilerin teolojik ve politik varsayımlara dayandığı ve Hıristiyanlık başta olmak üzere büyük dinlerin tahakkümüne hizmet ettiğine yöneliktir. Bu paradigmanın aşılması noktasında her ne kadar din kavramının gözden geçirilmesi gerektiği ileri 
sürülmekle birlikte mevcut durumda dini araștırmalarda inanan merkezli fenomenolojik yaklaşımı tatbik etmenin, -ism/izm ekiyle Batı merkezli din anlayıșına hizmet eden isimlendirmelere karşı en yakın- en azından içerik açısından- çözüm olduğu düşünebilir. Bunun yanı sıra mevcut durum, din bilimcilerin dini araştırmalarını belli kategoriler etrafında incelemeye odaklanmaları yerine, dini bütün yönlerini kapsayan, inanan odakll, disiplinler arası, sosyokültürel ve küresel konulara duyarlı dini araştırmalara duyulan ihtiyaca işaret etmektedir.

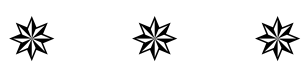

\section{KAYNAKÇA}

ADAM, Baki. "Din Hakkında Genel Bilgiler". Dinler Tarihi El Kitabı. Ed. Baki Adam. Ankara: Grafiker Yayınları, 2015.

ADAMS, Charles Joseph. "Classification of Religions”. Erişim: 01 Aralık 2018. https://www.britannica.com/topic/classification-of- religions.

ALICI, Mustafa. "Dinler Tarihini Popülerleştirmek: Yaşayan Dünya Dinleri Adlı Çalışma Üzerine Bir Kaç Söz". Milel ve Nihal: İnanç, Kültür ve Mitoloji Araştırmaları Dergisi 4/2 (2007): 163- 171.

ALICI, Mustafa. Dinler Tarihinin Batılı Öncüleri. İstanbul: İz Yayıncılık, 2011.

ALICI, Mustafa. Evrimci Politeizm Devrimci Monoteizm: Erken Kültürlerde Yüce Varlık Fikrine Etnolojik ve Fenomenolojik Yaklaşımlar. İstanbul: Rağbet Yayınları, 2013.

ARCHER, John Clark. Faiths Men Live By. New York: The Ronald Press Company, 1934.

AYDIN, Mahmut. Ana Hatlarıyla Dinler Tarihi: Tarih, İnanç ve İbadet İstanbul: Ensar Neşriyat, 2015.

AYDIN, Mehmet. Dinler Tarihine Giriş. İstanbul: Literatürk Academia, 2015.

BALDRICK-MORRONE, Tara- GRAZIANO, Michael- STODDARD, Brad. "Not a task for amateurs: Graduate instructors and Critical Theory in the World Religions classroom". After World Religions: Reconstructing Religious Studies. Ed. Christopher R. Cotter, David G. Robertson London, 37- 47. New York: Routledge, 2016.

BOUQUET, Alan Coates. Comparative Religion: A Short Outline. London: Penguin Books, 1953.

COX, James L. From Primitive to Indigenous: The Academic Study of Indigenous Religions. Hampshire, Burlington: Ashgate, 2007.

COX, James L. “Before the 'After' in 'After World Religions' - Wilfred Cantwell 
Smith on the meaning and end of religion", After World Religions: Reconstructing Religious Studies. Ed. Christopher R. Cotter, David G. Robertson. XII- XVIII. London, New York: Routledge, 2016.

ELIADE, Mircea. Ebedi Dönüş Mitosu. Çev. Ümit Altuğ. Ankara: İmge Kitabevi, 1994.

GÜNDÜZ, Şinasi. “Giriş". Yaşayan Dünya Dinleri. Ed. Şinasi Gündüz. 17-33. Ankara: D.İ.B. Yayınları, 2007.

HUME, Robert Ernest. The World's Living Religions. New York: Charles Scribner's Sons, 1924.

KARATAȘ, İbrahim Ethem. Max Müller: Hayatı, Eserleri ve Dinler Tarihindeki Yeri. Doktora Tezi, Dokuz Eylül Üniversitesi, 2006.

KELLET, Ernest Edward. A Short History of Religions. London: Victor Gollancz Ltd., 1933.

KING, Richard. "Taking on the guild: Tomoko Masuzawa and The invention of world religions". Method and Theory in the Study of Religion 20/2 (2008): 125-133.

KNOTT, Kim. "How to Study Religion". Religions in the Modern World: Traditions and Transformations. Ed. Linda Woodhead, Christopher Partridge, Hiroko Kawanami. 15-40. London: Routledge, 2016.

KUŞCU, Emir. “Türkiye'de Din Fenomenolojisiyle İlgili Yayınlar Üzerine Bir Değerlendirme". I. Ü. İlahiyat Fakültesi Dergisi 2/1 (2011): 127-154.

KÜÇÜK, Abdurrahman- TÜMER, Günay- KÜÇÜK, Mehmet Alparslan. Dinler Tarihi. Ankara: Berikan Yayınevi, 2009.

LEEUW, Gerardus Van der. Religion in Essence and Manifestation Princenton, New Jersey: Princeton University Press, 1986.

MARTIN, Douglas- HEVESI, Dennis. "Huston Smith, 'Author of the Worlds Religions', Dies at 97". Erişim: 12 Ocak 2019. https://www.nytimes.com/2017/01/01/us/huston-smith-authorof-the-worlds-religions-dies-at-97.html.

MASUZAWA, Tomoko. "World Religions". Encyclopedia of Religion (Second Edition). Ed. Lindsay Jones. 14: 9800-9804. New York: Macmillan Reference, 2005.

MASUZAWA, Tomoko. The Invention of World Religions: Or, How European Universalism Was Preserved in the Language of Pluralism. Chicago, London: The University of Chicago Press, 2005.

MOLENDIJK, Arie L. “Religious Development: C.P. Tiele’s Paradigm of Science 
of Religion". Numen 51/3 (2004): 321-351.

MÜLLER, Max. Introduction to the Science of Religion. London: Longmans, Green, and Co., 1882.

NOSS, David S.- GRANGAARD, Blake R. A History of the World's Religions. New Jersey: Pearson Higher Education, 2011.

NOSS, David S.- NOSS, John B. A History of the World's Religions. New York: Macmillan, 1990.

NOSS, John B. Man's Religions. New York: The Macmillan Company, 1949.

NOSS, John B. Man's Religions. New York: The Macmillan Company, 1963.

OWEN, Suzanne. "The World Religions paradigm Time for a Change". Arts \& Humanities in Higher Education 10/3 (2011): 253- 268.

ÖZCAN, Şevket "Ancient Origins of the History of Religions: Herodotus Example”, Ilahiyat Tetkikleri Dergisi 51/1 (2019): 395-417

PARTIN, Harry B. "Classification of Religions". Encyclopedia of Religion (Second Edition), Ed. Lindsay Jones. 3: 1817-1822. New York: Macmillan Reference, 2005).

SAUSSAYE, Chantepie de la. Manual of the Science of Religion. London: Longmans, Green and Co., 1891.

SHARPE, Eric. J. Nathan Söderblom and The Study of Religions. London: University of North California, 1990.

SHARPE, Eric J. Dinler Tarihi: Tarihsel Bir Anlatı. Çev. Fuat Aydın. Sakarya: Sakarya Üniversitesi Kültür Yayınları, 2013.

SMART, Ninian. The Religious Experience of Mankind. New York: Charles Scribner's Sons, 1969.

SMART, Ninian. Dimensions of the Sacred: An Anatomy of the World's Beliefs, Berkeley. London: Harper Collins, University of California Press, 1996.

SMITH, Huston. The World's Religions: Our Great Wisdom Traditions. New York: Harperone, 1998.

SMITH, Jonathan Z. Map is Not Territory: Studies in the History of Religions. Chicago, London: The University of Chicago Press, 1993.

SMITH, Jonathan Z. Relating Religion: Essays in the Study of Religion. Chicago, London: The University of Chicago Press, 2004.

SMITH, Wilfred Cantwell. The Meaning and End of Religion. New York: Mentor Books, 1964.

TAIRA, Teemu. "Doing Things with 'Religion': A Discursive Approach a 
Rethinking the World Religions Paradigm", After World Religions: Reconstructing Religious Studies. Ed. Christopher R. Cotter, David G. Robertson. 75-91. London, New York: Routledge, 2016.

TIELE, Cornelius P. "Religions". The Encyclopedia Britannica. 20: 358-371. Edinburgh: Adam and Charles Black, 1886.

TIELE, Cornelius P. Outlines of the History of Religion to the Spread of the Universal Religions. London: Kegan Paul, Trench, Trübner, 1896.

TIELE, Cornelius P. Elements of the Science of Religion: Part I. Morphological. Edinburgh: William Blackwood and Sons, 1898.

TÜMER, Günay. “Din”. Türkiye Diyanet Vakfi İslam Ansiklopedisi. 9: 312-320. Ankara: TDV Yayınları, 1994.

TYLOR, Edward Burnett. Primitive Culture: Researches Into The Development of Mtyhology, Philosophy, Religion, Art and Custom. London: John Murray, Albemarle Street, 1871.

ÜNAL, Mustafa. Din Fenomenolojisi: Tarihçe, Yöntem ve Uygulama. Kayseri: Geçit Yayınları, 1999.

WHITNEY, William D. "On the So-Called Science of Religion". Princeton Review 57/1 (1881): 429-452.

WOODHEAD, Linda- FLETCHER, Pau- KAWANAMI, Hiroko- SMITH, David (Eds.). Religions in the Modern World: Traditions and Transformations. London: Routledge, 2002.

WOODHEAD, Linda- PARTRIDGE, Christopher- KAWANAMI, Hiroko (Eds.). Religions in the Modern World: Traditions and Transformations. Ed. Linda Woodhead, Christopher Partridge, Hiroko Kawanami. London: Routledge, 2016.

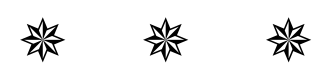




\title{
MORPHOLOGICAL APPROACH IN CLASSIFICATION OF RELIGIONS FROM THE PAST TO PRESENT
}

\author{
(1) Şevket ÖZCAN ${ }^{a}$
}

\section{Extended Abstract}

The origins of researching the religious beliefs of others by modern historians of history, it is based to the $5^{\text {th }}$ centuries BC. Therefore, evolving and expanding data about religious beliefs and practices in the historical process made it necessary to use different methods and approaches that will enable to understand and analyze this data in a correct, systematic and comprehensively way. In this context, the method of classifying religions according to certain categories within in the framework of the religious materials obtained has been formed and has been used by updating by many Eastern and Western religious researchers from the past to the present. From the second half of the nineteenth century, approaches of classification of religions have take over with increasing the number of classification of religions attempts and their using in religious studies.

It is possible to evaluate the views of the source of religion, especially used in religious studies in the West until the mid-twentieth century, prevailed in the second half of the nineteenth century as the first manifestations of the classification of morphological religions. Because, in these theories, religions were evaluated according to a categorical scale that reached from the understanding of the monotheistic god to the politeist understanding of God. In this discussion atmosphere that is animated by evolutionary theories, Max Müller's classification of religions in the context of language theory when gives an academic impetus to studies, basically Tiele, who is one of the architects of the Religion Phenomenology, has gained the title of being the scholar who systematized the classification of the morphological religions.

a Asst. Prof., Kırıkkale University, ozcan.sevket06@gmail.com 
Tiele who offers to examine the religions as a whole and with minds that is refined from all kinds of prejudice by drawing attention to the morphological and ontological aspects of religions stipulates to make comparisons in order to gain the scientific characteristic of the History of Religions. Therefore, he aims to classify the religions in morphological style and to make comparisons and to show similarities and differences of religions with other religions. In this respect, Tiele's making the categorization of religions as moral religions and including the category of universal / world religions under this category became a turning point in terms of the classification of morphological religions and had a significant impact on the following classification of the religions. The most important contribution of Tiele to the field of religious studies in the context of the classification of morphological religions is opening the door slightly to the spread of the concept of world religions, previously used in different languages, in the academic circles dominated by English language and raising awareness about the issue. As a matter of fact, this process has extended up to shaping academic and popular studies, in places that History of Religions studies are concentrated notably in America and England, on the axis a list of religions that the religions of Christianity, Buddhism, Islam, Hinduism and Judaism are permanent members; Confucianism, Taoism, Shintoism, Jainism, Sikhism and Zoroastrianism are also frequently used.

Since the 1960s, in academia and the world of education notably in the United States and England, because of the widespread use of the concept of world religions, criticisms of the classification of religions of morphological character have also been made in this context. In this process, Wilfred Cantwell Smith and Ninian Smart, who were particularly influential in their field, were the first religious scholars who challenged to studies representing the paradigm of world religions in similar ways. Following them, Jonathan Z. Smith's view that the Western History of Religions literature was shaped by the Western-Eastern dilemma inspired Tomoko Masuzawa's work The Invention of World Religions (2005) and the views of two religious scientists have allowed James L. Cox to describe the using and dominating of Western religions categories and concepts in religious studies as the paradigm of world religions. In this context, based on the examples of studies of History of Religions, it is possible to see that the category of world religions in morphological character is being used as a top category under these studies, regardless of which religions are classified and say this situation covers many studies in the field.

In general, it is accepted as the criticisms of the paradigm of world religions 
in the context of the morphological approach are based on theological and political assumptions and the signing essences serve the domination of Christianity or the great religions. As emphasized by various scholars, such as Cox, different understandings has emerged such as the concept of religion should be reassessed and the religions cannot be understood by isolating from their contexts, believers, sociocultural and global themes for overcoming the paradigm of world religions. This emphasizes the need for religious studies that cover all aspects of religion, believer oriented, interdisciplinary, and socio-cultural and sensitive global issues rather than addressing religions around certain categories.

Keywords: History of Religions, Religion, Classification, Morphology, World Religions.

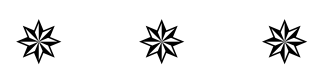

